\title{
Nyílt rendszerú magmás folyamatok: magmakeveredés, kristálycsere és kumulátum-recirkuláció nyomai a Ditrói alkáli masszívumban (Orotva, Románia)
}

\author{
Heincz Adrián ${ }^{1, *}$, PÁl-MolnáR Elemér ${ }^{1,2, *}$, Kiss Balázs ${ }^{1,2, *}$, BATKi Anikóón ${ }^{1,2}$, Almásı Enikő Eszter ${ }^{1}$, KiRI Luca ${ }^{1}$ \\ ${ }^{1}$ SZTE TTIK Ásványtani, Geokémiai és Kőzettani Tanszék „Vulcano” Kőzettani és Geokémiai Kutatócsoport, 6722 Szeged, Egyetem u. 2. \\ ${ }^{2}$ MTA-ELTE Vulkanológiai Kutatócsoport, 1117 Budapest, Pázmány Péter sétány 1/C \\ *A szerzôk megosztott első szerzőként egyenlő mértékben járultak hozzá a közlemény elkészítéséhez
}

\section{Open-system magmatic processes: magma mingling, crystal transfer and cumulate recycling in the Ditrău Alkaline Massif(Jolotca, Romania)}

Abstract

The Tarnița Complex represents the characteristic ultramafic and mafic rock assemblage of the northern part of the Ditrău Alkaline Massif, exposed in the Eastern Carpathians (Romania). The $\sim 60 \mathrm{~m}^{2}$ surface of the artificial outcrop in the intrusive igneous rock is located in the western part of the complex, near the interflow of the Pietrăriei de Sus and Jolotca creeks. It provides a unique insight into the mingling and mixing processes which occurred between magmas (a) in the former magma storage system and (b) during the incorporation of the earlier crystallized magmatic fragments entrained during the new magma intrusions.

The host rock of the studied section (grey, medium- and coarse-grained diorite with an oriented texture) comprises four different types of mafic magmatic enclave (MME): (i) mafic enclave; (ii) feldsparaggregatic enclave; (iii) porphyritic (feldsparaggregatic), mafic enclave and (iv) ultramafic enclave. In addition, a felsic xenolith type of distinct origin is also present: some of the felsic diorite enclaves are hosted in mafic enclaves, thus suggesting they were transported by the recharging mafic magma into the magma chamber.

The most important feature of the magma mingling process is the presence of fine-grained, lens-shaped, elongated mafic magmatic enclaves parallel with each other and with the orientation of the minerals in the host rock. The rock wall shows this typical magma mingling structure and implies that mafic recharge was a dominant process during the evolution of the magma storage system. The angular felsic xenoliths and ultramafic enclaves indicate the recycling of earlier cumulates by the intruding magmas. The mafic rim of the mafic magmatic enclaves and the nearby black bands ("schlieren") represent additional important characteristics of the mingling structures.

The magma mixing process is often accompanied by crystal transfer. The studied minerals show several microtextural features which can be related to this crystal transfer process between the intruding magma and the host magma, as well as between the intruding magma and the recycled cumulates. These are the plagioclase crystals characterized by different zoning patterns and inclusion contents, the pyroxene crystals mantled by amphibole, and the acicular apatite inclusions in the plagioclase. The detailed petrographic investigations presented in this study point to the complex and diverse evolution of the magma storage system of the Ditrău Alkaline Massif and to the dominant role of open-system magmatic processes.

Keywords: diorite, microtexture, open-system magmatic processes, mingling, crystal transfer, cumulate recycling, Ditrău Alkaline Massif

Összefoglalás

A Tarnița Komplexum a Keleti-Kárpátokban (Románia) felszínre bukkanó Ditrói alkáli masszívum északi területének jellemző ultramafikus és mafikus kőzetegyüttese. A komplexum Ny-i részén, az Orotva-patak és a Felsô-Pietrăriei-patak összefolyásánál található mélységi magmás kőzettestben kialakított mesterséges feltárás egyedülálló betekintést enged az egykori magmatározóban zajlott, több magma között lejátszódott keveredési és elegyedési folyamatokba, illetve az új magmabenyomulások során feltépett, korábban kikristályosodott magmás kôzetfragmentumok bekeveredési folyamataiba.

A feltárásban látható befogadó kôzetben (szürke, közép- és durvaszemcsés, irányított szövetú diorit) négy különböző keveredési kőzetzárvány (mafikus kőzetzárvány; földpátszemes kőzetzárvány; porfíros (földpátaggregátumos), mafikus kőzetzárvány és ultramafikus kőzetzárvány) és egy eltérő eredetű felzikus kőzetzárvány típus figyelhető meg. A keveredési kőzetzárványok modális összetételük alapján mezokrata és melanokrata dioritok, valamint piroxénhornblenditek, a felzikus kőzetzárványok pedig hololeukokrata dioritok. 
A különböző magmák közötti keveredés (mingling) legfontosabb bélyege az egymással — és a befogadó kőzet ásványainak orientált elhelyezkedésével — párhuzamos, megnyúlt, finomszemcsés, lencse alakú kôzetzárványok megjelenése. A szögletes felzikus xenolitok és ultramafikus kőzetzárványok korábbi kumulátumok recirkulációját feltételezik, amelyek a benyomuló magmával kerültek a magmatározóba. A keveredési kőzetzárványok mafikus pereme és a közelükben megfigyelhetô „slírek” további fontos jellemzői a legalább két magma keveredése során kialakuló szerkezeteknek.

A magmaelegyedés gyakori velejárója a kristálycsere (crystal transfer). A vizsgált ásványok számos esetben mutatnak olyan jellegzetes mikroszöveti bélyegeket, amelyek e kristálycsere-folyamathoz köthetôk a benyomuló és a befogadó magma, illetve a benyomuló magma és a feltépett kumulátumok között: a különféle zónásságot mutató és különböző zárványgazdag plagioklászok, az amfibolköpennyel rendelkező piroxének és a plagioklászokban megjelenő tűs apatitkristályok.

A jelen tanulmányban bemutatott részletes petrográfiai vizsgálatok rávilágítanak a Ditrói alkáli masszívum magmatározóinak összetett és változatos fejlődéstörténetére, amelyben meghatározó szerepet játszottak a nyílt rendszerú magmás folyamatok.

Tárgyszavak: diorit, mikroszövet, nyílt rendszerü magmás folyamatok, magmakeveredés, kristálycsere, kumulátum-recirkuláció, Ditrói alkáli masszívum

\section{Bevezetés}

A magmás petrogenezis megértéséhez kulcsfontosságú a magmatározókban zajló folyamatok (asszimiláció, kristályosodás, kristálykása-remobilizáció) feltárása, amelyeknek alapvető hatásuk van a magmák litoszférabeli fejlódésére és a vulkáni múködésre. A tektonika révén exhumálódó fosszilis magmatározók, vagyis a plutonok vizsgálata lehetôvé teszi ezeknek a folyamatoknak a leírását, megértését. A plutoni és vulkáni kôzetek, valamint ezek kôzetalkotó kristályainak integrált szöveti és kémiai vizsgálata rámutatott a nyílt rendszerú petrogenetikai folyamatok alapvető szerepére a magmatározók fejlődésében (pl.: DAVIDSON et al. 2007a, b; HuMPHREYs et al. 2006; TIEPOLO et al. 2011; SмITH 2014).

A Ditrói alkáli masszívum (DAM) vizsgálata során korábban már számos szerző hangsúlyozta a nyílt rendszerú magmás folyamatok szerepét (KoCH 1879; STRECKEISEN 1938, 1954; ANASTASIU \& CONTANTINESCU 1979, 1980; PÁLMolnár 1998, 2000; Morogan et al. 2000; PÁL-Molnár et al. 2015a). A DAM északi részén (Orotva-patak völgye) felszínre bukkanó Tarnița Komplexum (PÁL-MolNÁr 2000) vizsgálata során Morogan et al. (2000) és PÁL-Molnár (2000) is nyílt rendszerú folyamatokkal magyarázták terepi és petrográfiai megfigyeléseiket, valamint geokémiai adataikat.

A Tarniţa Komplexum kőzeteinek természetes feltárásai mellett a Felső-Pietrăriei-patak és az Orotva-patak összefolyásának közelében található mesterséges feltárás egyedi bepillantást enged az egykori magmatározóban zajlott petrogenetikai folyamatokba. E mesterséges feltárás egy bányászati cég előkutatásának eredménye, amelynek során a feltárásban vágott kőzetfelszíneket alakítottak ki, kiváló lehetőséget biztosítva így a kőzetek terepi tanulmányozásához. A vizsgált feltárást felépítő kőzetek irányítottsága, a kerekded, sötét, finomszemcsés lencsék, lencsesorok megjelenése dinamikus magmakeveredési folyamatokra utalnak.

E tanulmányban ismertetjük a feltárásban megjelenő kôzetek petrográfiai, szerkezeti és szöveti jellemzőit, valamint kísérletet teszünk az egykori magmatározóban történt nyílt rendszerú keveredési folyamatok leírására is.

\section{A Ditrói alkáli masszívum földtani környezete}

A Gyergyói-havasok (Munții Giurgeu) (Románia) D-i, DNy-i részét képező DAM $200 \mathrm{~km}^{2}$-en bukkan a felszínre. A masszívum petrográfiailag és szerkezetileg változatos és összetett felépítésú. Legfontosabb kőzettípusai az ultramafikus kumulátumoktól (hornblenditek), a gabbrókon, a dioritokon, a monzonitokon, a szieniteken és a nefelinszieniteken át a gránitokig terjednek, ezeket a kôzeteket lamprofír-, tinguait- és szienittelérek járják át.

A DAM a Keleti-Kárpátok kristályos mezozoos kőzettömegébe nyomult be és ezekkel a metamorf kőzetekkel együtt vett részt az alpi tektonikai eseményekben (pl. PÁLMolNÁr 1994a, b, c). Szerkezetileg a Bukovinai-takaróhoz tartozik (1. ábra, A) és annak négy prealpi terrénumával (litocsoportjával) (Bretila-, Rebra-, Negrişoara- és Tulgheşterrénum) van kontaktusa (BALINTONI 1997, BALINTONI et al. 1983, PÁl-Molnár 2000, BaLintoni et al. 2009, Balintoni \& BALICA 2013, BALINTONI et al. 2014). A DAM-ot a felszínen teljes egészében a Tulgheş-terrénum kőzetei övezik, jól követhetô szaruszirt zónával, így rétegtani korrelációja nem lehetséges, mivel közvetlen kontaktusa üledékes kőzetekkel sehol sem figyelhető meg. A DAM által áttört prealpi (variszkuszi) takarók a saali tektogenezis paroxizmusában keletkeztek (kora-perm), a Bukovinai-takaró pedig a kréta (ausztriai) orogén fázis során jött létre. A magmabenyomulás kapcsolatba hozható a Melléte-Hallstatt-óceán felnyílásával (HoECK et al. 2009), ahol a riftesedés a pelsói alkorszakban kezdődött (Kozur 1991). A masszívumot felépítő magmás kőzetek képződése $\mathrm{K}-\mathrm{Ar}$, $\mathrm{Ar}-\mathrm{Ar}$, valamint $\mathrm{U}-\mathrm{Pb}$ radiometrikus koradatok alapján ladin-nori $(237,4 \pm 9,1-217,6 \pm 8,3$ millió év) (Dallmeyer et al. 1997, PanĂ et al. 2000; PÁl-Molnár 2000, 2008; PÁL-MolNÁr \& ÁRVA-Sós 2005).

\section{Az ultramafikus és mafikus kózetek kutatástörténete}

A DAM elsô, 1833-as irodalmi említése (LILIENBACH 1833) óta a petrológiai kutatások középpontjában áll. Az elmúlt több mint másfél évszázad kutatásai (PÁL-MolNÁR 


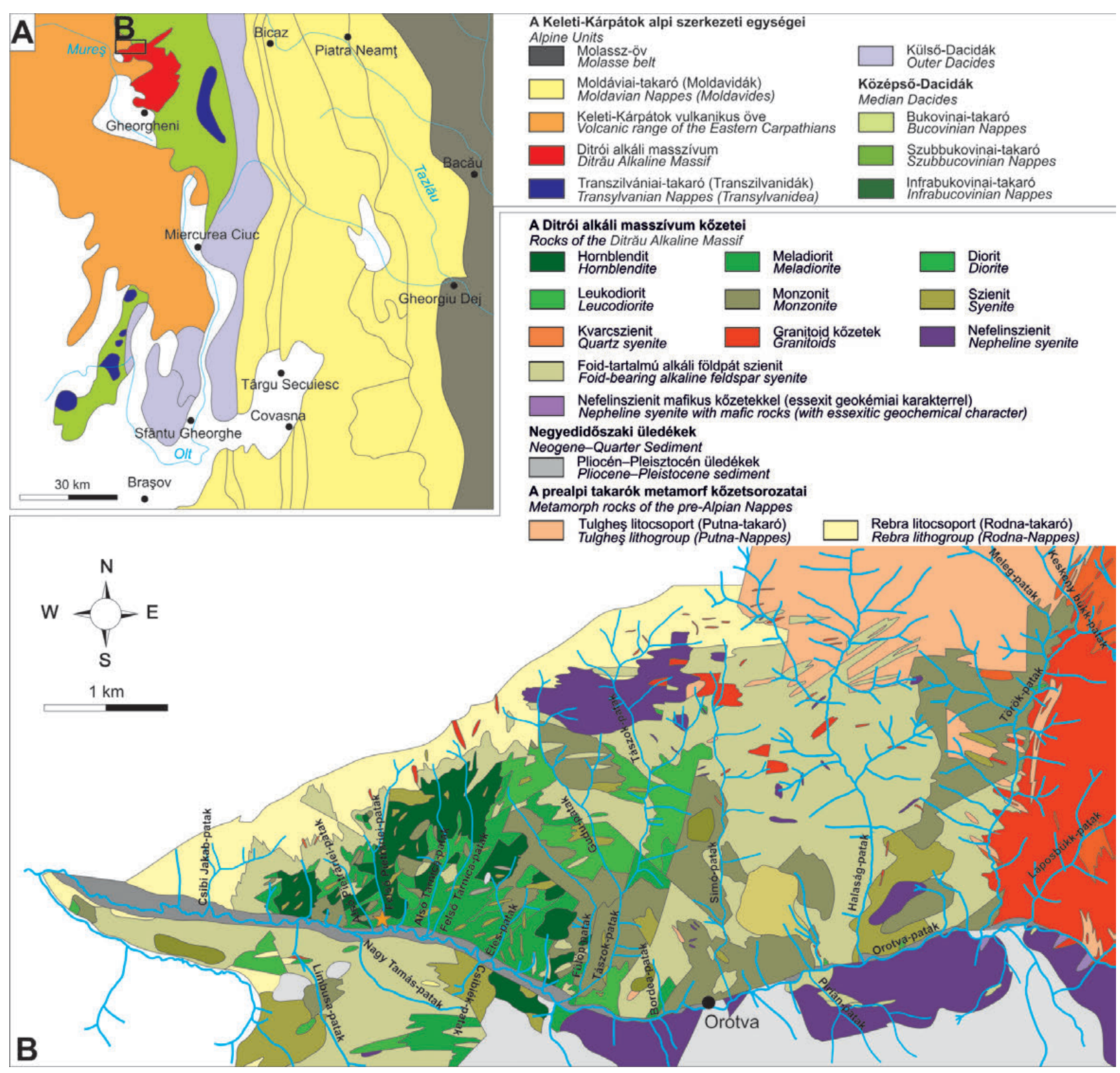

1. ábra. A) A Ditrói alkáli masszívum földtani helyzete a Keleti-Kárpátok alpi szerkezeti egységeiben (Pál-MoLnÁR 2010a, SĂNDULESCU et al. 1981 után módositva); B) A Ditrói alkáli masszivum északi részének kőzettani térképe (PÁL-MoLNÁr 2000); (sárga csillag = mintavételi pont)

Figure 1. A) Location of the Ditrău Alkaline Massif in the East Carpathians alpine orogenic system (PÁL-MOLNÁR 2010a, modified after SĂNDULESCU et al. 1981); B) Geological map of the northern part of the Ditrău Alkaline Massif (PÁL-MOLNÁR 2000); (yellow star = sample location)

1994a, 2000) — a térség politikai hovatartozásától függetlenül — alapvetốen meghatározták a hazai és főleg a nemzetközi magmás petrográfia nevezéktanának kialakulását. A DAM részletes kutatásának legfontosabb eredményei STRECKEISEN (1952, 1954, 1960), CODARCEA et al. (1957), STRECKEISEN \& HunZIKER (1974), JAKAB et al. (1987), PÁLMolnár (1992, 1994a, b; 2010a, b), JAKAB (1998), MorOGAN et al. (2000), BAtKi et al. (2004, 2014, 2018), KovÁcs \& PÁLMolnÁr (2005), FAll et al. (2007), Almási et al. (2015), PÁL-MolNÁR et al. (2015a, b) nevéhez fúződnek.

A DAM északi, északnyugati részén az Orotva-pataktól északra, a Csibi Jakab-patak és a Simó-patak között a felszínen az ultramafikus és mafikus kôzetek vannak túlsúlyban (1. ábra, B). Ezek a kőzetek szerkezetileg nagyon változa- tosak, ebből adódóan kőzettani megítélésük az idők folyamán igen eltérô volt. IANOVICI (1933) a Tászok-patak és a Fülöppatak alsó szakaszán kibúvó irányított szövetú dioritokat az essexitek csoportjába sorolta. Megítélése szerint a kőzetek szövete palás-fluidális átmenet. Az ásványok kb. 70\%-a irányított, a kőzetek színindexe (M) 50\% körüli. STRECKEISEN (1938) ezeket az ,alkáligabbró-alkálidiorit jellegú” kőzeteket Orotva település után orotvitnak nevezte. Az ultramafikus és mafikus kőzeteket CODARCEA et al. (1957) a Diorit-hornblendit kőzetek Komplexumába sorolták és olivines piroxénhornblendit, piroxénhornblendit, hornblendit (irányított és irányítatlan szövetú hornblendit, pegmatoidos hornblendit), gabbroidok, diorit és dioritos gneisz (homogén slíres, inhomogén slíres) kőzettani kategóriákba csoportosították. 
STRECKEISEN \& HuNZIKER (1974) rámutattak arra, hogy a Ditrói alkáli masszívumban két dioritkomplexum van jelen. Az egyik az Orotva völgyének alsó szakaszán, a másik pedig a Cengellér- és Güdüc-patak övezetében. Ez utóbbi komplexum kőzetei a normál dioritoktól essexites kemizmusukban különböznek. Ezeket a kôzeteket a monzodioritokkal, nefelindioritokkal és nefelinmonzodioritokkal együtt ditro-essexiteknek nevezték. ANASTASIU \& CONSTANTINESCU (1979) az Orotva-Putna Szektor kôzetein belül az ultramafikus és mafikus kőzeteket két komplexumba, az Ultramafitok és mafitok, valamint a Dioritok Komplexumába sorolták. Szerintük az orotvai dioritos összetételú kőzetek sztratiform testeket, lencséket, „slíreket” (, slire” — rom.), fészkeket alkotnak, szöveti szempontból nagyon változatosak (pegmatoidos, normál- és mikroszemcsés, irányított és irányítatlan szövetek). E szerzők felhívták a figyelmet, hogy hornblendit-diorit átmenet a plagioklászok mennyiségi növekedésével és az amfibolok mennyiségi csökkenésével fokozatosan jön létre. Színindex (M) alapján a következő kőzettípusokat írták le: leukodioritok $(\mathrm{M}<25 \%)$ és dioritok $(\mathrm{M}=25-50 \%)$. ZóLYA \& ZÓlYA (1985, 1986) és PÁl-MolnáR (1988, 1992, 1994c, 1998, 2000) ásványtani és szöveti bélyegek alapján nagyon részletesen osztályozták a masszívum É-i részén felszínre bukkanó ultramafitokat és mafitokat (hornblenditek és dioritok). PÁL-MoLNÁR (2000) az ultramafitokon belül két (irányított szövetú peridotitok és gabbrók, valamint irányítatlan szövetú peridotitok és gabbrók), a mafitokon belül pedig három nagy csoportot (meladioritok, dioritok, leukodioritok) különített el. Ásványos összetétel és szerkezeti jellemzők alapján a három nagy csoportba az alábbi kőzettípusokat sorolta: 1.) meladioritok: irányított szövetú, irányítatlan szövetú és „,palás” jellegú meladioritok; 2.) dioritok: irányított szövetú, irányítatlan szövetû, eutaxitos szövetú és ataxitos szövetú dioritok; 3.) leukodioritok: irányított szövetú és irányítatlan szövetú leukodioritok.

A kôzettani térképről (1. ábra, B) egyértelmúen kitűnik, hogy az ultramafikus és mafikus kőzetek térben mindig egymás szomszédságában, egymással összefogazódva vagy egymás közti fokozatos átmenetben jelennek meg (PÁLMOLNÁr 2000). Nem célszerű sem kôzettanilag, sem genetikailag a hornblendit-gabbró-diorit kőzeteket külön komplexumokba sorolni. Egy bonyolult felépítésú és tektonikájú litosztratigráfiai egységről van szó, ahol szigorúan petrográfiai értelemben a kőzettípusok elkülöníthetők, de ez csak egy kis rész kiemelését jelenti az egységes egészből. Ezek a kőzetek nem csak petrográfiai, hanem petrogenetikai értelemben is értelmezésre szorulnak. Az ultramafikus és mafikus kőzettípusokat ezért PÁL-MolnÁr (1998, 2000) Tarniţa Komplexum (ejtsd: Tarnica; a tarniţa [rom.] szó jelentése: nyereg, fa[nyereg]) néven egy kőzetkomplexumba sorolta. Továbbá rámutatott arra is, hogy a dioritok teljeskőzet-geokémiai adataik alapján rokonságot mutatnak a kumulátum kőzetekkel, valamint kevert eredetet jeleznek. A dioritok kialakulását a kumulátumkőzetek (hornblenditek) és a szienitek keveredési szélsôtagjaiból vezette le. A keveredés három esetét említette: 1.) ,injekciós határzóna”ahol az olvadék (szienit) erek formájában, parciális beol- vasztás nélkül átjárja a mellékkőzetet (kumulátumok), és éles határfelületû keveredési szerkezeteket hoz létre; 2.) „injekciós határzóna részleges beolvasztással” — ahol az olvadék valamennyit beolvaszt a mellékkőzetből, ezáltal lekerekített, határvonalukban kevésbé éles keveredési kőzetzárványok jönnek létre; 3.) ,„permeációs határzóna”amely esetben a részleges ,,beolvasztás” (elegyedés) történik, a határzónák elmosódnak és eutaxitos, valamint ataxitos szövetú kőzetek alakulnak ki. A Tarnița Komplexumban található meladioritokat, dioritokat és leukodioritokat a különböző fokozatú keveredési és elegyedési folyamatok végtermékeiként értelmezte.

MorOGAN et al. (2000) részletesen vizsgálták a dioritkőzeteket. Az Orotva-völgy Ny-i részén változatos méretú, egyenetlen, megnyúlt peremmel rendelkező, kerek és lencseszerú, olykor ,pillow” formában megjelenő szerkezeteket írtak le. Véleményük szerint a mafikus (alkáligabbró, alkálidiorit) és felzikus (szienit és kvarcszienit) fáciesek közötti „pillow”-szerú megjelenés arra enged következtetni, hogy mafikus magma nyomult be felzikus magmába, bonyolult keveredési és elegyedési szerkezeteket eredményezve.

\section{Mintagyújtés, vizsgálati módszerek}

A kutatás alapját képező mintákat az Orotva-patak és a Felsô-Pietrăriei-patak összefolyásánál található közel sima felületû $3 \times 3$ m széles és 7 m magas kivágott tömb után visszamaradt mesterséges feltárásból gyűjtöttük (2. ábra). A feltárásban jól elkülöníthetők — és kőzettanilag makroszkóposan is definiálhatók - a Tarnița Komplexum változatos formájú és megjelenésú kőzetei. A különbözô szerkezeti helyzetben lévő kőzettípusokból 14 reprezentatív mintát dolgoztunk fel.

A mintavételhez nagy teljesítményű akkumulátoros fúrót használtunk. A fúróra egy egyedi igényekhez gyártott, $2,5 \mathrm{~cm}$ külsố átmérôjú, gyémántberakásos koronafúrót helyeztünk fel. A koronafúró maximálisan $5 \mathrm{~cm}$ mélységig képes behatolni a kőzetbe. Az így gyújtött minták átlagosan $3,5 \mathrm{~cm}$ hosszú, $2 \mathrm{~cm}$ átmérōjú hengerek.

A Szegedi Tudományegyetem Ásványtani, Geokémiai és Kőzettani Tanszékén a reprezentatív mintákból $30 \mu \mathrm{m}$ vastagságú, polírozott vékonycsiszolatokat készítettünk, és ezek részletes mikroszkópos vizsgálatát Brunel SP-300-P polarizációs mikroszkóppal végeztük. A fázisanalízishez THERMO DXR Raman-spektrométert használtunk.

A csiszolatok modális ásványos összetételét a Quantum GIS 2.14.0 térinformatikai szoftver segítségével határoztuk meg.

\section{A feltárás leírása}

A vizsgált mélységi magmás test szerkezete egy $\sim 60 \mathrm{~m}^{2}$ es sík felületú falon tanulmányozható (2. ábra). E fal egy inhomogén magmás kőzettestet tár fel, amely (feltételezhetôen áramlás következtében) irányítottságot, fluidális szerkezetet mutat. A feltárásban a világosszürke, irányított 
szövetű befogadó kőzetben finomabb szemcsés, sötétszürke, cm-dm-es mafikus kőzetzárványok figyelhetôk meg. E mafikus zárványok alakja általában lencseszerú,

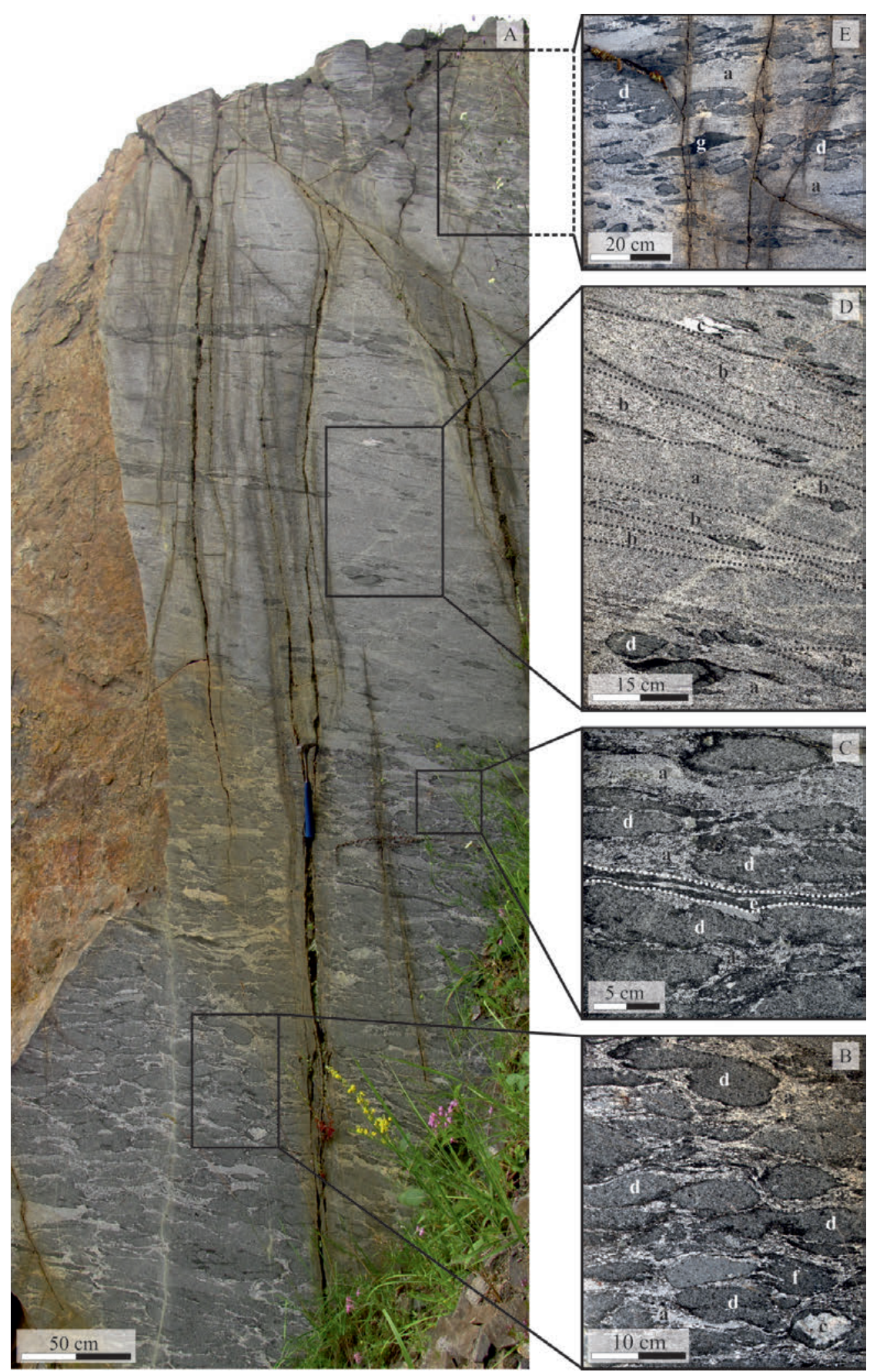

2. ábra. A - A Tarnița Komplexum mesterséges feltárása az Orotva- és a Felső-Pietrăriei-patak összefolyásánál; $\mathrm{B}-\mathrm{C}$ - A feltárás alsó része, ahol tömeges a mafikus keveredési kőzetzárványok megjelenése; $\mathrm{D}-\mathrm{A}$ feltárás középső, keveredési kőzetzárványokban szegény része; E - A mafikus lencsék eloszlása és megjelenése a feltárás felső részén

a) Szürke, középszemcsés, irányitott szövetủ befogadó kőzet; b) Szürke, durvaszemcsés, irányított szövetủ befogadó kőzet; c) Felzikus kőzetzárvány; d) Mafikus kőzetzárvány; e) Fekete, mafikus szalag („slír”); f) Porfíros (földpátaggregátumos), mafikus kỏzetzárvány; g) Ultramafikus kőzetzárvány.

Figure 2. A-Representative field photographs showing the studied artifical outcrop within the Tarnita Complex (Jolotca, Ditrău Alkaline Massif); B-C-Mafic enclaves are abundant especially in the lower part of the outcrop; $D$ - The middle part of the mafic enclave poorly outcrop; $E$ - The distribution and appearance of the mafic enclaves in the upper part of the outcrop

a) Grey, medium-grained host rock with oriented texture; b) Grey, coarse-grained host rock with oriented texture; c) Felsic xenolith; $d$ ) Mafic enclave; e) Black, mafic band ("schlieren"); f) Porphyritic mafic enclave with feldspar aggregates; g) Ultramafic enclave ritkán szögletes, és eloszlásuk a befogadó kőzetben nem egyenletes. A feltárt fal alsó és felsô szakaszán — akár 2 mes szélességben — a lencsék tömegesen feldúsulnak, a fal középsô részén viszont kisebb mennyiségben vannak jelen, olykor önállóan ,úsznak” a szürke, irányított szövetû kőzetben vagy $15-20 \mathrm{~cm}$ széles sávban lencsesorokat alkotnak (2. ábra, A).

A mafikus lencsék változó vastagságú és megjelenésú, még sötétebb peremmel jellemezhetők. E mafikus lencsék mellett elszórtan, kis mennyiségben — változó mérettel és alakkal — felzikus kőzetzárványok, illetve fekete mafikus szalagok (slírek) jelennek meg (2. ábra, $B-E$ ).

A feltárás a részletes makroszkópos vizsgálat alapján két nagyobb egységre osztható: a) a fő tömeget képviselő világosszürke, irányított szövetû befogadó kőzet és b) az ebben megjelenô változó méretû és formájú, sötét és világos lencsék és zárványok (3.ábra). A kőzettestben a makroszkópos szöveti bélyegek és a modális ásványos összetétel alapján az alábbi hét kőzetcsoport különíthető el: befogadó kózet: 1.) szürke, középszemcsés, irányított szövetû kőzet, 2.) szürke, durvaszemcsés, irányított szövetű kôzet; zárványok: 3.) felzikus kőzetzárvány, 4.) mafikus kőzetzárvány, 5.) földpátszemes kőzetzárvány, 6.) porfíros (földpátaggregátumos), mafikus kőzetzárvány, 7.) ultramafikus kőzetzárvány.

\section{A vizsgált magmás test petrográfiája}

A befogadó kőzet (host rock) és az abban található zárványok szövete minden esetben fanerokristályos, holokristályos, hipidiomorf szemcsés (jellemzőiket a 3. ábra foglalja össze). A fő kőzetalkotó ásványok: amfibol, piroxén, biotit, plagioklász, ritkán káliföldpát (ortoklász). Járulékos elegyrészként nagy mennyiségben titanit- és opakásványok (magnetit, pirit), illetve kis mennyiségben apatit megjelenése jellemző. Másodlagos ásványfázisok: a plagioklász rovására kialakuló kalcit, az amfibol és plagioklász rovására ki- 

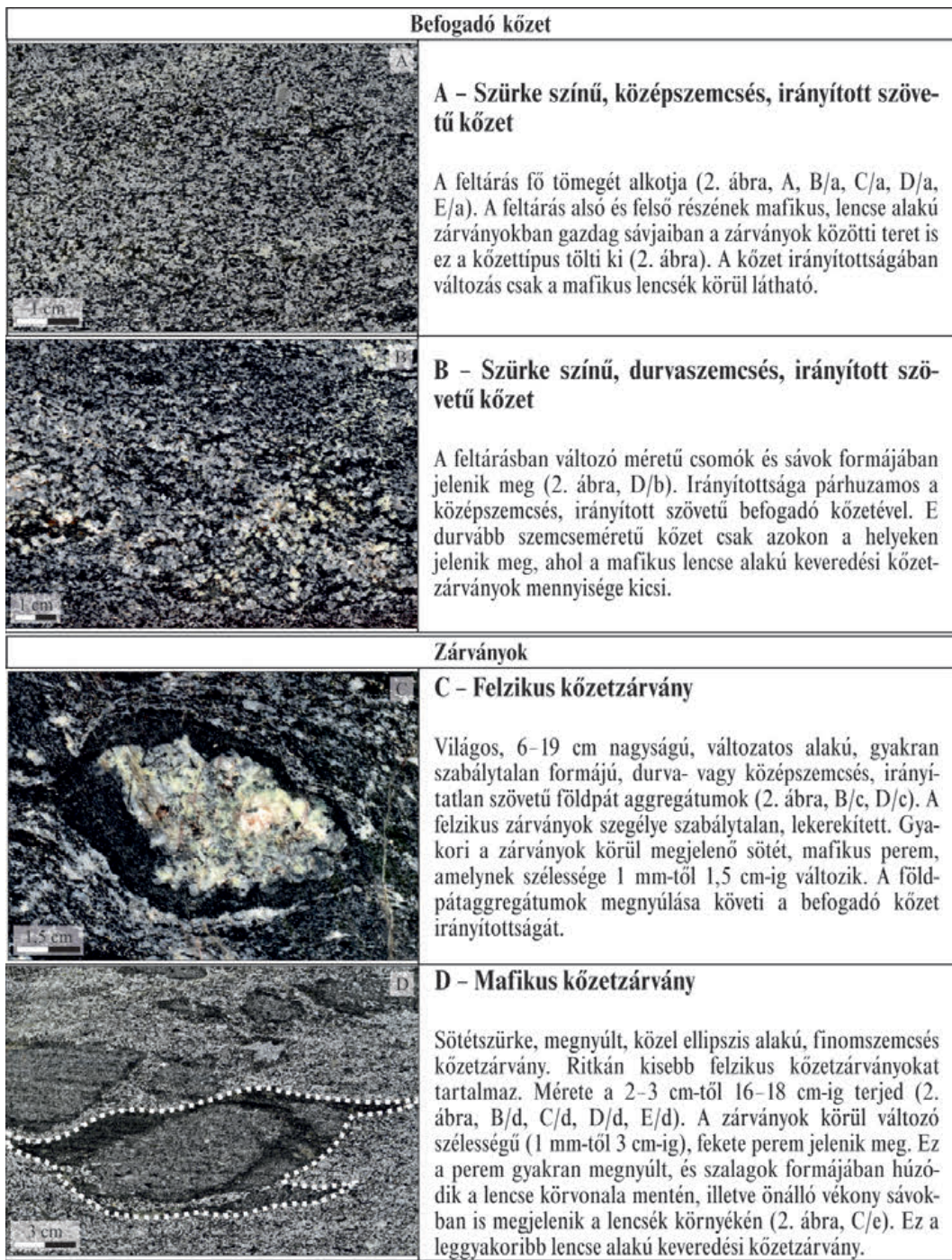

Zárványok

C - Felzikus kőzetzárvány

Világos, 6-19 $\mathrm{cm}$ nagyságú, változatos alakú, gyakran szabálytalan formájú, durva- vagy középszemesés, irányí tatlan szövetü földpát aggregátumok (2. ábra, B/c, D/c). A felzikus zárványok szegélye szabálytalan, lekerekitett. Gyakori a zárványok körül megjelenỏ sötét, mafikus perem, amelynek szélessége $1 \mathrm{~mm}$-töl $1,5 \mathrm{~cm}$-ig változik. A földpátaggregátumok megnyúlása követi a befogadó kőzet irányitottságát.

\section{D - Mafikus kőzetzárvány}

Sötétszürke, megnyúlt, közel ellipszis alakú, finomszemcsés kőzetzárvány. Ritkán kisebb felzikus kôzetzárványoka tartalmaz. Mérete a 2-3 cm-töl $16-18 \mathrm{~cm}-\mathrm{ig}$ terjed (2. ábra, B/d, C/d, D/d, E/d). A zárványok körül változó szélességü (1 mm-töl $3 \mathrm{~cm}-\mathrm{ig}$ ), fekete perem jelenik meg. Ez a perem gyakran megnyúlt, és szalagok formájában húzódik a lencse körvonala mentén, illetve önálló vékony sávokban is megjelenik a lencsék környékén (2. ábra, C/e). Ez a leggyakoribb lencse alakú keveredési közetzárvány.

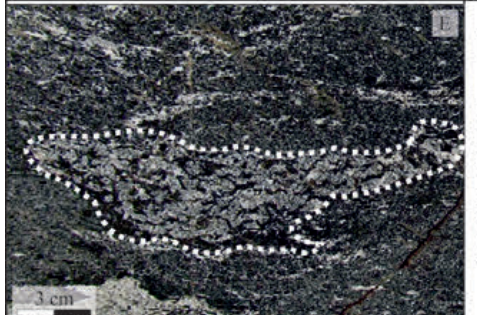

\section{E - Földpátszemes kőzetzárvány}

Megnyúlt, durvaszemcsés, irányitott szövetủ kőzetzárvány. Mérete $10-15 \mathrm{~cm}$ között változik. $1-7 \mathrm{~cm}-\mathrm{es}$ földpátokat tartalmaz, amelyeket keskeny, fekete mafikus sávok választanak el egymástól. A lencséket részben vagy teljesen körbeveszi egy sötét perem. Ez a zárványtípus a teljes feltárásra jellemzổ, eltérö mafikus-felzikus ásvány arányokkal.

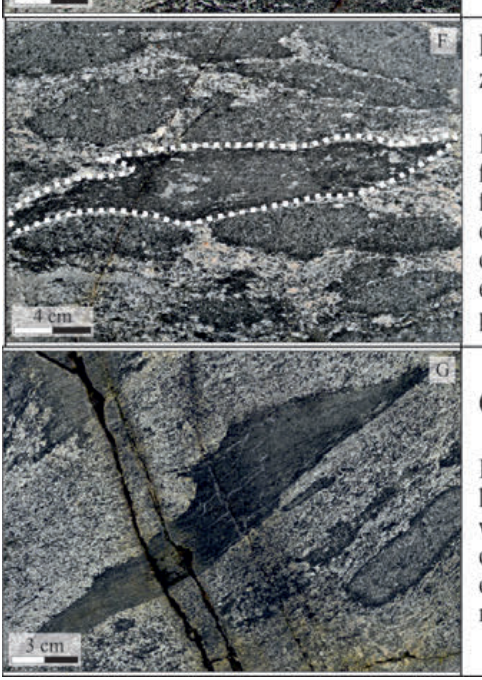

F - Porfíros (földpátaggregátumos), mafikus kőzetzárvány

Kis mennyiségben megjelenỏ zárványtipus. Sötétszürke, finomszemcsés, szögletes szegélyü, amelynek mérete és formája a $8 \mathrm{~cm}$-es megnyúlt alakzatoktól a 30-35 cm-es egységekig változik (2. ábra, $\mathrm{B} / \mathrm{f})$. Plagioklász porfiros elegyrészeket és aggregátumokat tartalmaz. Központi része ellipszoid alakú, irányitott szövettel. A jellemzö fekete perem szélessége 2-5 mm, amely leválhat a zárványról.

\section{G - Ultramafikus közetzárvány}

Fekete, finomszemcsés, irányitott szövetü kőzetzárvány. A lencsék nyúlt, szögletes szegélyü alakzatok. Ennél a zárványtípusnál is jellemzỏ egy fekete perem, amely egyenetlen, csipkézett és olykor egyes szakaszokon alig láthatóan elvékonyodik. Ritkán megjelenỏ zárványtípus (2. ábra E/g; mérete $24 \mathrm{~cm}$ ). alakuló epidot, az amfibol és biotit rovására kialakuló klorit, illetve az amfibol rovására kialakuló másodlagos biotit és titanit. Az egyes kőzetváltozatok modális összetétele az I. táblázatban látható. A területről származó korábbi kőzetminták geokémiai vizsgálata alapján a kőzetekben található plagioklászok An-tartalma kisebb, mint 50\% (PÁL-MolnÁR et al. 2000).

Mindezek alapján a vizsgált egységekben LE MAITRE et al. (2002) nevezéktana szerint az alábbi kőzetek különíthetôk el:

Befogadó kőzet (host rock): — szürke, középszemcsés, irányított szövetú kőzet — mezokrata diorit,

- szürke, durvaszemcsés, irányított szövetú kőzet - mezokrata diorit.

Zárványok (enclaves, xenoliths):

— felzikus kőzetzárvány — hololeukokrata diorit,

— mafikus kőzetzárvány — mezokrata diorit,

— földpátszemes kőzetzárvány — mezokrata diorit,

— porfíros (földpátaggregátumos), mafikus kőzetzárvány — melanokrata diorit, — ultramafikus kőzetzárvány — piroxénhornblendit.

\section{Szürke, középszemcsés, irányított szövetü közet (mezokrata diorit)}

A kőzet ekvigranuláris, irányított szövetû. Lényeges elegyrészei a plagioklász, az amfibol, a káliföldpát és a biotit (4. ábra, A).

A plagioklász hipidiomorf, táblás megjelenésú, mérete maximum 2000 m. Olykor erősen mállott, szericitesedett, epidotosodott. Gyakran tartalmaz titanit-, apatit-, amfibol- vagy opakásvány-zárványokat. A kőzetben kis mennyiségben hipidiomorf káliföldpát is megjelenik. Az amfibol hipidiomorf, oszlopos. Mérete 100 és $1500 \mu \mathrm{m}$ között változik, pleokroizmusa barna-világosbarna. A kis mennyiségben megjelenô, 2500-5000 $\mu$ m méretû szemcsék zónásak. Zárványként apatit-, titanit- és opak ásványszemcséket tartalmaz, átalakulási termékként epidot jelenik

3. ábra. A befogadó kőzetek és a különféle kőzetzárvány típusok makroszkópos jellemzői

Figure 3. Macroscopic features of the host rocks and the different enclave types 
I. táblázat. A vizsgált kőzettípusok modális összetétele

Table I. Modal compositions of the studied rock types

\begin{tabular}{|c|c|c|c|c|c|c|c|}
\hline$\sum_{\text {Aswint }}^{\text {Kizet- }}$ iipus & $\begin{array}{c}\text { Szz̈rke, } \\
\text { középszcmesces, } \\
\text { irányilotl } \\
\text { szövetü közct }\end{array}$ & $\begin{array}{c}\text { Szürke, } \\
\text { durvaszzmcsés, } \\
\text { irányílott } \\
\text { szövetü közct }\end{array}$ & $\begin{array}{c}\text { Folzikus } \\
\text { kớzelzárvány }\end{array}$ & $\begin{array}{c}\text { Matikus } \\
\text { kơzzetzárvány }\end{array}$ & $\begin{array}{l}\text { Földpátszemes } \\
\text { kơzelzárvány }\end{array}$ & $\begin{array}{c}\text { Porfíros } \\
\text { (földpát- } \\
\text { aggregátumos), } \\
\text { malikus } \\
\text { kózzctzárvány }\end{array}$ & $\begin{array}{l}\text { Ultramafikus } \\
\text { közetzárvány }\end{array}$ \\
\hline & \multicolumn{7}{|c|}{ V/V \% } \\
\hline Plagioklász & 54 & 56 & 91 & 40 & 54 & 29 & - \\
\hline Káliföldpát & 2 & 3 & - & - & - & - & \\
\hline Amfibol & 36 & 28 & 1 & 50 & 37 & 66 & 52 \\
\hline Klinopiroxén & $<1$ & $<1$ & - & - & - & 1 & 40 \\
\hline Biotit & 1 & 7 & 3 & 9 & 3 & 1 & $<1$ \\
\hline Titanit & 4 & 4 & 3 & $<1$ & 5 & 1 & 5 \\
\hline Apatit & $<1$ & $<1$ & $<1$ & $<1$ & $<1$ & 1 & 1 \\
\hline Opak & I & 1 & 1 & 0 & 1 & 2 & 2 \\
\hline Kalcit & - & $<1$ & 1 & - & - & - & - \\
\hline A & 4 & 5 & 0 & 0 & 0 & 0 & 0 \\
\hline$P$ & 96 & 95 & 100 & 100 & 100 & 100 & 0 \\
\hline M & 42,5 & 41 & 9 & 60 & 46 & 71 & 100 \\
\hline
\end{tabular}

huzamos elrendeződése okozza. A kőzetben kis mennyiségben hipidiomorf, oszlopos megjelenésú, 300-750 um méretú, enyhén átalakult klinopiroxének is találhatók.

A járulékos elegyrészek közül a titanit van túlsúlyban, amely idiomorf, ritkán hipidiomorf, tûs vagy levélboríték alakú. Mérete 250-1250 m között változik. A kőzetalkotó ásványok hossztengelyével párhuzamosan van jelen, és gyakori a halmazos megjelenése. Ritkán opak- és apatitásvány zárványokat tartalmaz: az apatit tûs, lekerekített, 10-300 $\mu \mathrm{m}$ nagyságú, az opak fázisok (magnetit, pirit) maximum $400 \mu \mathrm{m}$ méretúek és leggyakrabban xenomorfak. Elszórtan xenomorf kalcit is megjelenik.

meg benne. A kőzet irányítottságát az amfibol és a plagioklász párhuzamos sávokba rendeződése jelöli. Pikkelyes, táblás, xenomorf biotit kis mennyiségben van jelen. Sötét zöldesbarna-világosbarna pleokroizmust mutat, olykor idiomorf epidot- és lekerekített titanitzárványokat tartalmaz.

A járulékos elegyrészek nagy részét tûs vagy levélboríték alakú, gyakran lekerekített titanit szemcsék képviselik. Ezek irányítottan, az amfibol megnyúlásával párhuzamosan jelennek meg. Emellett idiomorf, tûs és oszlopos apatit is előfordul a szemcsék között vagy a kőzetalkotó ásványokban zárványként. Az opak ásványok (magnetit, pirit) nagy része xenomorf, de kis mennyiségben megjelennek idiomorf szemcsék is, főleg mafikus ásványok környezetében.

A másodlagos ásványok közül az epidot megjelenése jellemző amfibolban és biotitban.

\section{Szürke, durvaszemcsés, irányított szövetü kózet (mezokrata diorit)}

A kőzet inekvigranuláris, irányított szövetû. Lényeges elegyrészei a plagioklász, az amfibol, a biotit, a káliföldpát és a klinopiroxén (4. ábra, B).

A plagioklász hipidiomorf, táblás. Mérete 600-3500 $\mu \mathrm{m}$ között változik. A szemcsék gyakran szericitesedtek. Apatit-, titanit-, opakásvány- és ritkán amfibolzárványokat tartalmaz. Az amfibol hipidiomorf, oszlopos. Mérete 200 és $4800 \mu \mathrm{m}$ tartományban mozog, de általában 1000 $\mu \mathrm{m}$ a jellemző szemcsemérete. Biotitosodott és epidotosodott, illetve zárványként apatit-, titanit- és opakásvány-szemcséket tartalmaz. A biotit xenomorf, pikkelyes vagy táblás, ritkábban lemezes megjelenésû. Maximum 2500 m nagyságú. Peremén általában kloritosodott, valamint titanit-, apatit- és opakásvány-zárványokat tartalmaz. A kőzet irányítottságát a plagioklász, az amfibol és a biotit megnyúlásával pár-
A kőzet általános hipidiomorf szemcsés, irányított szövete mellett gyakran jellemző, hogy a plagioklászok közötti intersticiális térben aprószemcsés amfibolból (150-800

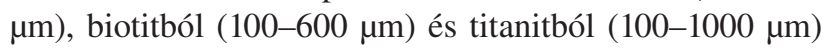
álló halmazok jelennek meg, amelyek elválasztják egymástól a földpátokat; az irányítottság ezeken a részeken is megegyezik a kőzet általános szövetével.

\section{Felzikus kózetzárvány (hololeukokrata diorit)}

E kőzetzárvány típus inekvigranuláris, irányítatlan szövetû (4. ábra, C). Lényeges elegyrészei a plagioklász, kis mennyiségben biotit és/vagy amfibol, illetve kalcit.

A plagioklász a zárványok több mint 90 térfogat\%-át alkotja. Hipidiomorf, táblás, mérete 250 és $7500 \mu$ m között változik. Gyakran erôsen mállott, szericitesedett, epidotosodott. Apatitot, titanitot és opak ásványokat, illetve ritkán 250-300 um méretú amfibolzárványokat tartalmaz. A plagioklászok mellett kis mennyiségben található biotit és/vagy amfibol. A biotit több esetben másodlagos, amely az amfibol rovására alakult ki, ezek mellett gyakran láthatók opak- és epidotszemcsék is. Az elsődleges biotit hipidiomorf vagy xenomorf, maximum $1500 \mu$ m nagyságú. Sötétzöld, sötétbarna-világosbarna pleokroizmusa jellemző, gyakran kloritosodik. Apatit-, opakásvány- és titanitzárványokat tartalmaz. Az amfibol hipidiomorf, oszlopos, mérete nem haladja meg a $2500 \mu \mathrm{m}$-t. Erôs kloritos és biotitos átalakulása jellemző a peremek és hasadások mentén. Kis mennyiségben elsődleges xenomorf kalcit is megfigyelhető.

A járulékosan megjelenő titanit idiomorf, ritkán hipidiomorf, maximum 1250 mm nagyságú. Erősen repedezett, valamint apatit- és opakásvány-zárványokat tartalmaz. Az apatit idiomorf, 50-200 ㅆm méretú, gyakran zárványként 

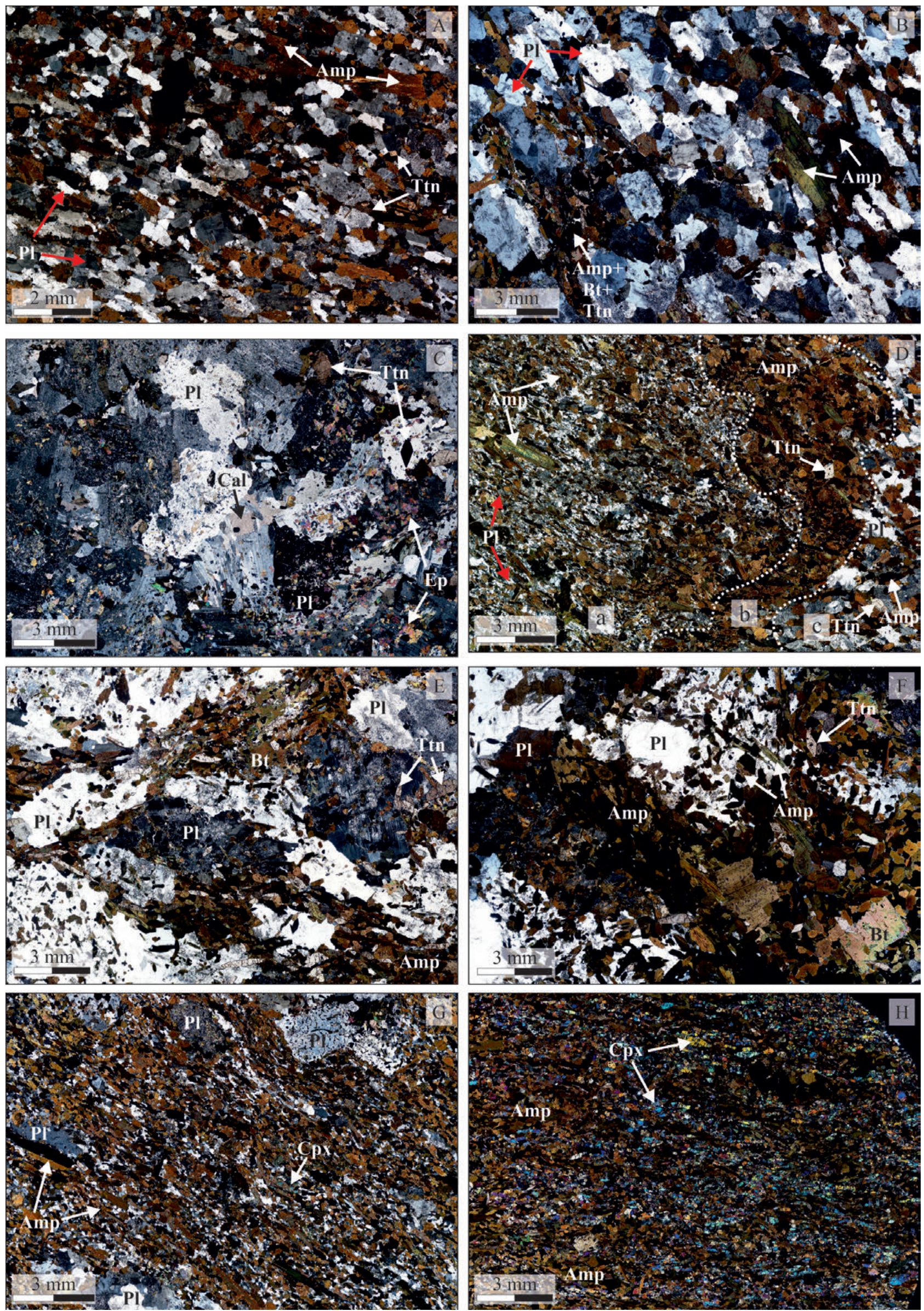
jelenik meg a legtöbb ásványban. Az opak ásványok (magnetit, pirit) főleg amfibol és biotit közelében fordulnak elő, alakjuk változatos, méretük maximum $750 \mu \mathrm{m}$.

Másodlagos ásványként klorit és epidot jellemző. A klorit szálas, rostos megjelenése általános, olykor repedéskitöltô. Az epidot plagioklász átalakulása során jött létre.

\section{Mafikus kózetzárvány (mezokrata diorit)}

Inekvigranuláris, irányított szövetû kőzetzárvány. Lényeges elegyrészei az amfibol, a plagioklász és a biotit (4. ábra, D).

A plagioklász hipidiomorf vagy xenomorf. Mérete 50 és $625 \mu \mathrm{m}$ közötti, minden esetben szericitesedett. Apatit- és titanitzárványokat tartalmaz. Helyenként aggregátumok formájában is megjelenik, ilyenkor a szemcsék üdék. Az amfibol hipidiomorf-xenomorf, oszlopos megjelenésû,

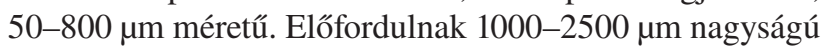
zónás amfibolkristályok is. Sötétzöld, sötétbarna-világosbarna pleokroizmus jellemzi. Sávokban vagy esetenként az ásványok magjában szagenitrácsok jelennek meg. A szemcsék széle sokszor egyenetlen, öblös megjelenésú, illetve a peremükön néha biotitos átalakulás figyelhető meg. Kis mennyiségben titanit-, apatit- és opakásvány-zárványokat tartalmaz. A megnyúlt amfibolok egymással párhuzamos elrendeződése jelöli ki a lencséken belüli szöveti irányítottságot. A biotit hipidiomorf, ritkábban xenomorf, pikkelyes vagy táblás, 250-2500 $\mu$ m méretú. Sötétzöld-világosbarna pleokroizmus jellemzi. Szélei egyenetlenek, peremén kloritosodott. Nagy mennyiségben tartalmaz apatit-, opakés másodlagos titanitzárványokat. A titanit a legtöbb esetben a szemcsék peremén jelenik meg.

A járulékos elegyrészeket a titanit és az apatit képviselik. A két ásvány közül a kőzetben a titanit található nagyobb mennyiségben. Idiomorf, mérete 25-500 $\mu$ m között változik. Általában zárványként, ritkán pedig a szemcsék között jelenik meg. Az apatit idiomorf, 50-175 $\mu$ m méretú, gyakori zárvány plagioklászban, amfibolban, biotitban, de megjelenik önállóan is.

A kőzet legjellemzőbb másodlagos ásványfázisa az epidot, emellett a szericit és a biotit gyakori.

A mafikus kőzetzárványokat változó szélességű (0,5 mm$3 \mathrm{~cm}$ ), fekete perem veszi körül, amelyet az alábbiak jellemeznek. Szinte kizárólag amfibol alkotja, amely hipidiomorf, oszlopos megjelenésú, 100-1750 m nagyságú. E peremben a normál zónás és sávokban megjelenő zárványokat tartalmazó amfibolok is gyakoriak. Az amfibol általában apatitzárványokat és jól meghatározható sávokban szagenitrácsokat tartalmaz, ritkábban erősen átalakult piroxén is megjelenik benne. Az amfibolok c-tengelyei közel párhuzamosan helyezkednek el. Felzikus ásványt nem, vagy alig tartalmaz. Ha megjelenik felzikus ásvány, az minden esetben plagioklász, amely xenomorf és a szemcsék közti teret tölti ki. A klinopiroxén általában hipidiomorf, 250$750 \mu \mathrm{m}$ nagyságú, néha elérheti a $800 \mu \mathrm{m}$-t is. Ritkán a klinopiroxént amfibolköpeny veszi körbe. A biotit xenomorf, pikkelyes megjelenésú, kissé kloritosodott. Mérete maximum $1750 \mu \mathrm{m}$. Sok zárványt tartalmaz: apatit, titanit, opak ásványok (magnetit, pirit) és néha epidot. A zárványok mennyisége olykor poikilites szövetet eredményez. Ez a fekete perem a szürke, középszemcsés, irányított szövetú befogadó kőzetben fekete mafikus sávok formájában is megjelenik, amely szövetükben és ásványos összetételükben is megegyeznek a mafikus lencséket körülölelő peremmel (4. ábra, $D)$.

\section{Földpátszemes kózetzárvány (mezokrata diorit)}

Inekvigranuiláris, irányított szövetû kőzetzárvány (3. ábra, $E-F$ ). Lényeges elegyrészei a plagioklász, az amfibol és a biotit.

Legnagyobb mennyiségben plagioklász alkotja, amely hipidiomorf, táblás 250-7000 ㅆm méretú, néhol erôsen szericitesedett, epidotosodott. A nagy méretú (1000-7000 $\mu \mathrm{m})$ plagioklászok kétféle poikilites szövettel jelennek meg: a) az egyik esetben a plagioklász nagyszámú, közel azonos méretű amfibol- (100-600 $\mu \mathrm{m})$, titanit-, apatit- és opakásvány-zárványokat (chadakristályokat) tartalmaz. A zárványok a plagioklászban (oikokristályban) elszórtan, irányítatlanul helyezkednek el, a plagioklászok 100-500 $\mu \mathrm{m}$ széles pereme viszont jóval kevesebb zárványt tartalmaz (4. ábra, E); b) a másik poikilites csoport esetében a zárványok a plagioklászok peremében jelennek meg, a szemcsék belsô, magrésze zárványmentes (4. ábra, F). Megfigyelhető, hogy a zárványok követik a zárványmentes mag körvonalát, mintegy körbeölelik azt, míg a perem többi részén orientálatlan az elhelyezkedésük. A zárványok mérete — a magtól a perem felé - egyre nagyobb. Az alapanyagban: a plagioklászszemcsék (50-150 $\mu \mathrm{m})$ az amfibolok között jelennek meg. Az amfibol hipidiomorf, oszlopos és lekerekített, maximum $2500 \mu \mathrm{m}$ nagyságú. Pleokroizmusa sötétbarna, sötétzöld-világosbarna. Az amfibolszemcsék magjában vagy koncentrikus zónáiban a sûrû zárványdúsulások fénymikroszkóppal nem jellemezhetők, de feltételezhetően ezek szagenitrácsok. Az amfibolok egyenes szemcseélúek, hármas szemcsehatárokkal. A plagioklászok körül jelennek

$\leftarrow$ 4. ábra. A befogadó kőzetek és a bennük található különböző kőzetzárványok petrográfiai jellemzői (polarizációs mikroszkópos képek)

A - Szürke, középszemcsés, irányított szövetű befogadó kőzet (mezokrata diorit; $+\mathrm{N}$ ); B - Szürke, durvaszemcsés, irányított szövetű befogadó kőzet (mezokrata diorit; +N); $\mathrm{C}-$ Felzikus kőzetzárvány (hololeukokrata diorit; +N); D - Mafikus kőzetzárvány (a - mezokrata diorit) és szürke, középszemcsés, irányított szövetű befogadó kőzet (c) kontakt mafikus peremmel (b) $(+\mathrm{N}) ; \mathrm{E}-\mathrm{F}-$ Földpátszemes kőzetzárvány két különböző szöveti megjelenése (mezokrata diorit; $+\mathrm{N}) ; \mathrm{G}-$ Porfíros (földpátaggregátumos), mafikus kőzetzárvány (melanokrata diorit; +N); $\mathrm{H}$ - Ultramafikus kőzetzárvány ( piroxénhornblendit; $+\mathrm{N}$ )

$\leftarrow$ Figure 4. Micrographic features of the host rocks and their different enclaves (polarization microscopic images)

$A-$ Grey, medium-grained host rock with oriented texture (mesocratic diorite; $+N$ ); $B-$ Grey, coarse-grained host rock with oriented texture (mesocratic diorite, $+N$ ); $C-F e l s i c x e n o l i t h($ hololeucocratic

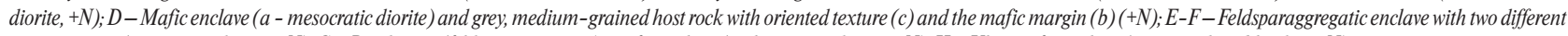
textures types (mesocratic diorite, $+N)$; $G-$ Porphyritic (feldsparaggregatic), mafic enclave (melanocratic diorite, $+N$ ); $H-$ Ultramafic enclave (pyroxene hornblendite, $+N$ ) 
meg irányítottan, azokat elválasztva egymástól. A kőzetben kis mennyiségben xenomorf, pikkelyes, táblás, maximum $1000 \mu \mathrm{m}$ méretú biotitszemcsék találhatók. A biotitok apatitzárványokat tartalmaznak és peremükön enyhén kloritosodtak. Pleokroizmusuk sötétbarna, szélükön sötétzöldvilágosbarna.

A 150-2250 $\mu \mathrm{m}$ méretú titanit szinte mindig lekerekített. A plagioklászokban lévő titanitzárványok irányítatlanok, a szemcsék közötti térben megjelenő titanitok az amfibol megnyúlásával párhuzamosan helyezkednek el. Az idiomorf apatit- és a hipidiomorf opakásvány-szemcsék (magnetit, pirit) zárványként vagy a szemcsék közötti térben figyelhetők meg.

\section{Porfíros (földpátaggregátumos), mafikus kózetzárvány (melanokrata diorit)}

Inekvigranuláris, irányított szövetú, lényeges elegyrészei az amfibol, a plagioklász, a piroxén és a biotit (4. ábra, $G$ ).

E mafikus zárványtípusban a plagioklászok porfíros elegyrészként, illetve aggregátumok formájában és intersticiálisan is megjelennek. Az alapanyagban a hipidiomorf vagy xenomorf plagioklászok mérete 100-250 $\mu \mathrm{m}$, enyhén szericitesedett. A porfíros elegyrészként előforduló plagioklász hipidiomorf, táblás, 300-2500 m méretú, valamint gyakran epidotosodtak és szericitesedtek. A megnyúlt aggregátumok formájában megjelenó plagioklászok 0,5-1 cm nagyságúak, és két típusuk különíthető el. Az egyik típust 5-7 mm hosszúságú csomók képviselik, amelyek ritkán tartalmaznak zárványokat. A másik esetben a plagioklászok poikilitesek, zárványként nagy mennyiségben tartalmaznak oszlopos megjelenésú, irányítatlanul, elszórtan elhelyezkedő idiomorf amfibolokat (100-400 $\mu \mathrm{m})$, apatitokat és opakásványokat. A földpátszemcséknek esetenként 50-200 $\mu \mathrm{m}$ vastag, zárványszegény peremük van. Mindkét esetben az aggregátumok hossztengelye az amfibolok hossztengelyével párhuzamos. Az amfibol hipidiomorf, oszlopos. Ritkán nagy (2000-3750 ㅆm) méretú porfíros elegyrészként jelenik meg, de átlagosan 50-1250 um nagyságú. Helyenként erősen repedezett, illetve némelyikben közel koncentrikus szagenitrácshalmaz észlelhető. A szemcsék minden esetben egymással párhuzamosak. A kőzetben kis mennyiségben megjelenik a klinopiroxén is. Általában xenomorf vagy hipidiomorf, 400 $\mu$ m-es, enyhén zöldes pleokroizmusú. Normál zónás, kissé átalakult (amfibolosodott). A plagioklász aggregátumokban is előfordul idiomorf, nagyméretú $(750 \mu \mathrm{m})$ szemcsékként. A biotit xenomorf, pikkelyes, táblás, mérete 750-2250 $\mu \mathrm{m}$, pleokroizmusa sötétbarna, sötétzöld-barna, zöld. A kőzetben kis mennyiségben található, elvétve titanit-, apatit- és opakásvány-zárványokat tartalmaz.

Az akcesszórikus elegyrészek közül a titanit idiomorfhipidiomorf, tús vagy ék alakú. Maximum 600 m nagyságú, olykor repedezett. A lényeges elegyrészek c-tengelyével párhuzamosan helyezkedik el, főleg a mafikus kôzetalkotók között jelenik meg. Ritkán zárványként van jelen amfibolban és biotitban. További akcesszórikus elegyrészek az apatit és az opak ásványok (magnetit, pirit), amelyek zárványként vagy kôzetalkotó ásványok között figyelhetők meg. Az idiomorf opak fázisok jelentős mennyiségben fordulnak elő a poikilites földpátban.

\section{Ultramafikus kózetzárvány (piroxénhornblendit)}

Ekvigranuláris, irányított szövetú kőzetzárvány, amelyben a lényeges elegyrészek az amfibol és a piroxén (4. ábra, $H$ ).

Az amfibol hipidiomorf, oszlopos, átlagosan 150-300 $\mu \mathrm{m}$ méretú, de a nagyobb szemcsék mérete eléri az 1000-3500 $\mu \mathrm{m}-\mathrm{t}$ is. Sötétbarna, sötétzöld, világos sárgásbarna pleokroizmus jellemzi. Ritkán apatit-, titanit-, klinopiroxén- és opakásvány-zárványokat tartalmaz. Az egymással érintkező amfibolok élei egyenesek és kontaktusukat a hármas szemcsehatárok jellemzik. A klinopiroxén hipidiomorf, oszlopos megjelenésú, 150-1000 ㅆm nagyságú. Halványzöld, gyenge, alig észlelhetô pleokroizmussal. Opakásványzárványokat tartalmazhat, a peremeken és a hasadási nyomvonalak mentén kismértékû kloritosodás nyomai láthatók. Az amfibolok és a piroxének megnyúlása közel párhuzamos egymással. Kis mennyiségben megjelenik xenomorf, leme-

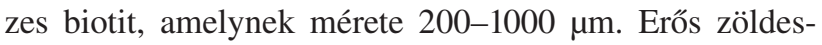
barna-világosbarna pleokroizmusa van, és a peremein kloritosodott. Titanit-, illetve ritkán amfibol- vagy klinopiroxénzárványokat tartalmaz.

Akcesszórikus elegyrészek a titanit, az apatit és az opak ásványok (magnetit, pirit). A titanit idiomorf, ék alakú vagy tûs megjelenésú. Mérete maximum $250 \mu \mathrm{m}$, ritkán zárványként jelenik meg. Az apatit idiomorf, 20-300 $\mu$ m nagyságú, olykor zárványként fordul elő amfibolban. Az opak szemcsék xenomorfok, méretük maximum $200 \mu \mathrm{m}$, és gyakran a piroxének körül jelennek meg.

\section{Diszkusszió}

\section{Magmakeveredési és magmaelegyedési folyamatok}

A magmás rendszerek változatos kőzetsorozatainak kialakulása különböző differenciációs folyamatokhoz köthetô, mint például frakcionációs kristályosodás, falkőzetasszimiláció, többszörös magmabenyomulások, magmakeveredés.

A hazai szaknyelvben a magmakeveredés kifejezést különböző folyamatokra használjuk, amelyeket fontos egymástól elkülöníteni. A magmakeveredés lehet csak fizikai keveredés (magma mingling), azonban ha két magma kémiailag is elegyedik egymással, vagyis olvadékolvadék keveredés is zajlik, akkor kémiai elegyedésről (magma mixing) beszélünk (DINGWELL 2009). A következőkben ezért kitérünk a fogalmak pontos jelentésére és javasoljuk, hogy a későbbiekben a hazai szaknyelvben ha magmakeveredésről van szó — az alábbi magyar fogalmakat használjuk. 


\section{Magmakeveredés (mingling)}

Ha két eltérô kémiai összetételú magma a keveredés során nem alakít ki egy új, homogén, köztes összetételú magmát, akkor keveredésről beszélünk (FrosT \& MAHOOD 1987). Keveredés esetén a magmák „együtt mozognak, miközben megtartják egyedi tulajdonságaikat" (MicHEL et al. 2016), vagyis egy heterogén keverék jön létre, amelyben „diszkrét" csomagok formájában vannak jelen a keveredő szélsőtagok.

\section{Magmaelegyedés (mixing)}

FROST \& MAHOOD (1987) az elegyedést két eltérő kémiai összetételú magmának a keveredéseként értelmezik, amely során egy új, homogén, hibrid magma jön létre. Az elegyedés eredményét tehát két magma „kombinációjaként” lehet értelmezni (Michel et al. 2016), ahol a létrejövő hibrid magma (vagy magmák) homogén(ek) és köztes geokémiai összetételt, a keveredô szélsôtagok között lineáris trendet mutat(nak) (CAMPOS et al. 2002).

A két folyamat általában együtt megy végbe, és gyakran eredményez finomszemcsés lencséket, amelyeket az angol nyelvú szakirodalom ,,mafic magmatic enclave” vagy „,mafic microgranular enclave" (MME) (mafikus magmás enklávé vagy mafikus finomszemcsés enklávé) néven említ (CAMPos et al. 2002, Michel et al. 2016). Ezek a lencsék általában sötétebbek (mafikusabbak), mint a befogadó kôzet. Jelen tanulmányban keveredési kőzetzárványnak nevezzük ôket.

\section{Magmakeveredés makroszkópos bélyegei a vizsgált magmás kózetekben}

A magmakeveredés során kialakuló makroszkópos bélyegekkel számos tanulmány foglalkozik (FROST \& Mahood 1987, Wiebe et al. 2001, Valesco-TaPia et al. 2013, FARNER et al. 2014, WeIDENDORFER et al. 2014, Michel et al. 2016, MA et al. 2017).

A Ditrói alkáli masszívum egykori magmatározójában olyan szerkezeti és szöveti bélyegek figyelhetók meg, amelyek egy igen dinamikus magmás rendszerre engednek következtetni. Egy ilyen dinamikus rendszer múködését az interakcióba lépő magmák fizikai és kémiai tulajdonságai határozzák meg. A keveredés során a benyomuló magma (magma intrusion) szétoszlik a nagyobb tömeget képviselő befogadó magmában (host magma). A benyomuló magmát az önálló, kerekded, „lencse alakú keveredési kôzetzárványok" (enclaves) (FROST \& MAHOOD 1987, Wiebe et al. 2001, CAMPos et al. 2002, McCulloch 2007. Peytcheva et al. 2008, Georgiev et al. 2009, FARNER et al. 2014, WeIDENDORFER et al. 2014, Michel et al. 2016) képviselik.

Az általunk vizsgált feltárásban a nagyobb tömeget képviselő szürke, közép- és durvaszemcsés, irányított szövetú befogadó kôzetben nagy mennyiségben láthatók sötétszürke, elnyúlt, ellipszoid vagy kissé szögletes alakú, cm-dm nagyságú lencse alakú keveredési kőzzetzárványok (2. ábra). Kialakulásuknak oka a benyomuló magma diszpergálódása az áramló közegben, továbbá fontos szerepe van a nagy húlési rátának is, mivel a magmák között nem tud fizikai és kémiai egyensúly kialakulni, amikor kevés idő áll rendelkezésre a kristályosodáshoz, ahogy ezt hasonló rendszerekben feltételezik (Frost \& MAHOOD 1987, WIEBE et al. 2001, Campos et al. 2002, Peytcheva et al. 2008, Michel et al. 2016). E kôzetzárványok megnyúlási iránya egymással és a befogadó kőzet kôzetalkotó ásványainak kitüntetett irányával közel párhuzamos (2. ábra, $B-E)$, amely folyamatos mozgásra utal. A szerkezeti és szöveti irányítottságot feltételezhetően az intenzíven áramló magma alakítja ki (CAmpos et al. 2002, MA et al. 2017), mint pl. a Sierra Nevada-i Lamarck Granodiorit esetében is (FrosT \& MAHOOD 1987); itt leggyakrabban konvekciós áramlásokról van szó (Hassanen 1999, Couch et al 2001, Peytcheva et al. 2008). A kózetzárványok megnyúlásának és a kőzetalkotó amfibolok c-tengelyének közel azonos orientációja is erre vezethetô vissza.

A lencse alakú formák (keveredési kőzetzárványok) a feltárás felső és alsó részén akár $2 \mathrm{~m}$ szélességben is felhalmozódnak (2. ábra, $B, C, E$ ), a középső részen viszont csak elszórtan jelennek meg (2. ábra, D). Ezt az arculatot - a magmatározóban végbemenő áramlások mellett — a többszörös magmabenyomulás is eredményezheti (mint pl. a Sredna Gorában, Bulgáriában vagy a Hortavær Magmás Komplexumban, Norvégiában - MCCulloch 2007, Peytcheva et al. 2008, Georgiev et al. 2009). Szinte minden keveredési kőzetzárvány körül látható egy, a zárványnál mafikusabb perem, amely változó vastagságban jelenik meg. E perem 1.) két magma közötti nagy hőmérsékletkülönbségből adódó (Frost \& MAHOOD 1987, MCCuLLOCH 2007) dermedési folyamathoz (quenching) köthetô „,megdermedt” peremként (chilled margin) értelmezhetố; és/vagy 2.) kialakulásáért a benyomuló magmából a kristályosodás során felszabaduló és a két magma határán feldúsuló könnyenillók a felelősek. A könnyenillók felhalmozódása elősegíti a víztartalmú ásványok (amfibol, biotit) kristályosodását és ennek eredményeként egy reakcióperem jön létre a zárványok körül (FARNER et al. 2014). Nem zárható ki e két folyamat együttes szerepe sem, de ezeknek a folyamatoknak a magabiztos értelmezéséhez áványkémiai adatokra van szükség. Hasonló zárványok láthatók többek között az Espinharas Hibrid Komplexumban, Brazíliában (CAMPOS et al. 2002), a Vinalhaven Intrúzióban, Maine-ben (WIEBE et al. 2001) vagy az Austurhorn Intrúzióban, DK-Izlandon (WEIDENDORFER et al. 2014) is.

A feltárásban több helyen láthatók sötét, elnyúlt sávok — úgynevezett „slírek” - (2. ábra, C), amelyek vagy a lencse alakú keveredési kôzetzárványoktól elszakadva, de azok közelében, vagy azokhoz kapcsolódva jelennek meg (pl. MA et al. 2017). A szakirodalom (pl. FARNER et al. 2014) e szerkezetek kialakulását a „slíreket” alkotó ásványok gyengébb folyási tulajdonságaival (reológiájával) magyarázza. 
A magmaelegyedés mikroszkópos szöveti bélyegei: kristálycsere (crystal transfer)

A magmaelegyedés eredményeként több olyan mikroszöveti bélyeg is kialakul, amelyek információval szolgálnak e nyílt rendszerú folyamatról, valamint az abban részt vevő magmák fejlődéséről. A kristálycsere (crystal transfer) a különböző reológiai tulajdonságú magmák elegyedésének jellemző folyamata, ugyanis ezek a magmák gyakran tartalmaznak korai kristályokat, amelyek a hibridizáció során mechanikailag cserélődnek. A megváltozott fizikai és kémiai környezet hatással van a korai ásványokra, befolyásolja azok fejlődését, amely tükröződik mind szöveti jellemzôikben, mind kémiai összetételükben (UBIDE et al. 2014). Ezek a szöveti bélyegek nem egyensúlyi reakciók következményei, és elsősorban plagioklász-, piroxén- és apatitásványokon figyelhetők meg (GoRDON 2002, UBIDE et al. 2014, Michel et al. 2016, MA et al. 2017).

Az általunk vizsgált magmás kőzettestben az elegyedési folyamatok leggyakoribb szöveti bélyege a befogadó kőzetben és a legtöbb kôzetzárványban megfigyelhetô zónás plagioklászkristályok és a plagioklász oikokristályok jelenléte (5. ábra. $A, B, C, D$ ) (hasonlóan, mint például a Sázava intrúzióban - JANOUŠEK et al. 2004, a Gangdese Batholitban - MA et al. 2017, vagy az Albtal Plutonban Michel et al. 2016). A porfíros (földpátaggregátumos), mafikus kőzetzárványokban megfigyelhető, hogy a plagioklász oikokristályokban lévô chadakristályok (amfibol, titanit, magnetit, pirit) méretében nincs jelentős változás a plagioklász magjától kifelé haladva. A plagioklásznak emellett van egy vékony zárványszegény pereme (5. ábra, C). Az ilyen típusú oikokristályok kialakulásának oka a helyi felfútés lehet, amelyet a magmatározóba újonnan benyomuló mafikus magma idéz eló, miközben bekebelezi a korábban kikristályosodott plagioklászt. Ezek a plagioklász kristályok gyakran alkotnak aggregátumokat (5. ábra, $D$ ). A földpátszemes kőzetzárványban megfigyelhetô plagioklász oikokristályokban a chadakristályok (amfibol, titanit, opak fázisok [magnetit, pirit], illetve biotit) átlagos szemcseméretének - a magtól a perem felé történő - fokozatos növekedése jellemzó. A plagioklászok magja zárványmentes és kerekded. A chadakristályok a kerekded mag körvonalával párhuzamosan jelennek meg, majd a magtól távolodva orientálatlanná válnak (5. ábra, E). Valószínúsíthetô, hogy a magok által képviselt, korábban kikristályosodott plagioklászok egy új magmás környezetbe kerültek, ahol nem egyensúlyi körülmények között visszaoldódtak. Később, amikor a rendszer ismét elérte a plagioklász sta- bilitási tartományát, folytatódott a kristályosodás, és a továbbnövekedés a körülötte lévő kôzetalkotókkal egy időben zajlott. Hasonló megjelenésú plagioklászok az Albtal Pluton (Németország) kőzeteiben láthatók (Michel et al. 2016). Ezek a szöveti bélyegek arra utalnak, hogy a plagioklászok egy része nem volt egyensúlyban azzal a magmával, amelyben található. A magmakeveredés során a megváltozott körülmények (intenzív paraméterek és/vagy az olvadék összetétele) következtében visszaoldódtak, majd az új környezetnek megfelelő összetételú zóna kristályosodott rájuk (pl.: CASHMAN \& BLUNDY 2013, MA et al. 2017).

Több, különböző fizikai és kémiai tulajdonságú olvadékot tartalmazó és dinamikusan fejlődố magmás rendszerekben gyakran előfordulnak — a xenokristályokon kívül — olyan kikristályosodott szemcsék is, amelyek nem oldódtak vissza. A mafikus lencsék körül megjelenő peremben elvétve idiomorf piroxének is találhatók, amelyeket amfibolköpeny vesz körül (5. ábra, F). Az elegyedési folyamatok során - az eltérô kémiai összetétel és a gyors húlés következtében — kialakuló ásványránövekedés jól ismert folyamat a szakirodalomból (pl. Vinalhaven Island Pluton, GorDOn 2002, vagy Gangdese Batholit, MA et al. 2017).

A dermedési (,quenching”) folyamat során a hirtelen bekövetkező hőmérséklet-változás kikényszeríti az ásványok gyors kiválását, kevés idő́t hagyva a kikristályosodásra. A dermedési folyamat tipikus bélyege pl. a földpátokban megjelenố tûs habitusú apatit is (5. ábra, $G$ ) (WYLLIE et al. 1962, Frost \& MAHOOD 1987, HibBard 1991, JANOUŠEK et al. 2000, BAXTER \& FEely 2002, Perugini et al. 2003, Michel et al. 2016, MA et al. 2017).

\section{Kumulátum-fragmentumok bekebelezése}

A feltárásban a legfeltúnőbb zárványtípusok az ultramafikus kôzetzárványok (piroxénhornblendit) és a felzikus kőzetzárványok (hololeukokrata diorit), amelyek megjelenésükben és ásványos összetételükben is jelentôsen különböznek a feltárás többi kőzetétől. Az ultramafikus kőzetzárványok elnyúlt, szögletes szélúek, amelyeket egy még sötétebb perem vesz körül, továbbá megnyúlási irányuk párhuzamos a befogadó kőzetben megfigyelhetô irányítottsággal és a környező zárványokéval. Összetételét tekintve zömében amfibolból (52 térfogat\%) és piroxénből (40 térfogat\%) áll, ezzel szemben a többi kőzetzárványból hiányzik a piroxén, vagy csak elszórtan, kis mennyiségben van jelen. Az ultramafikus zárványok jellemző mikroszkópi megjelenése a piroxén és az amfibol sávokba rendeződése

$\rightarrow$ 5. ábra. A magmakeveredési és magmaelegyedési folyamatokra utaló mikroszöveti bélyegek (optikai mikroszkópos képek)

A - Normál zónás plagioklász a szürke, középszemcsés, irányított szövetủ befogadó kőzetben $(+\mathrm{N})$; B - Foltos zónás plagoklászkristály szericites maggal és üde peremmel a szürke, durvaszemcsés, irányított szövetủ befogadó kőzetben $(+\mathrm{N})$; $\mathrm{C}-$ Azonos méretủ chadakristályok plagioklász oikokristályban a porfiros (földpátaggregátumos), mafikus kőzetzárványban (+N); D - Poikilites plagioklászokból álló aggregátum a porfíros (földpátaggregátumos), mafikus kőzetzárványban (+N); E - Zárványgazdag plagioklász zárványmentes maggal földpátszemes kőzetzárványban $(+\mathrm{N})$; F - Piroxénkristály amfibolköpennyel a fekete mafikus peremben $(+\mathrm{N}) ; \mathrm{G}-$ Tüs apatitzárványok plagioklászban a földpátszemes kőzetzárványban $(+\mathrm{N})$

$\rightarrow$ Figure 5. Microtextural features indicative of the magma mingling and mixing processes (optical microscopic images)

$A-$ Normally zoned plagioclase in the grey, medium-grained host rock with oriented texture $(+N)$; B-Patchy zoned plagioclase with sericitic core and fresh overgrowth rim in the grey, coarsegrained host rock with oriented texture $(+N) ; C-$ Chadacrystals of equal size in plagioclase oikocrystals in porphyritic (feldsparaggregatic), mafic enclave $(+N) ; D-P$ Poikilitic plagioclase

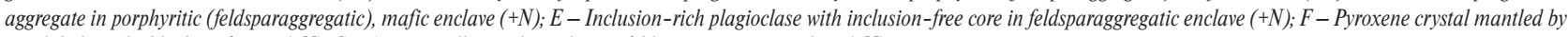
amphibole in the black mafic rim $(+N)$; $G-$ Apatit needles in plagioclase in feldsparaggregatic enclave $(+N)$ 

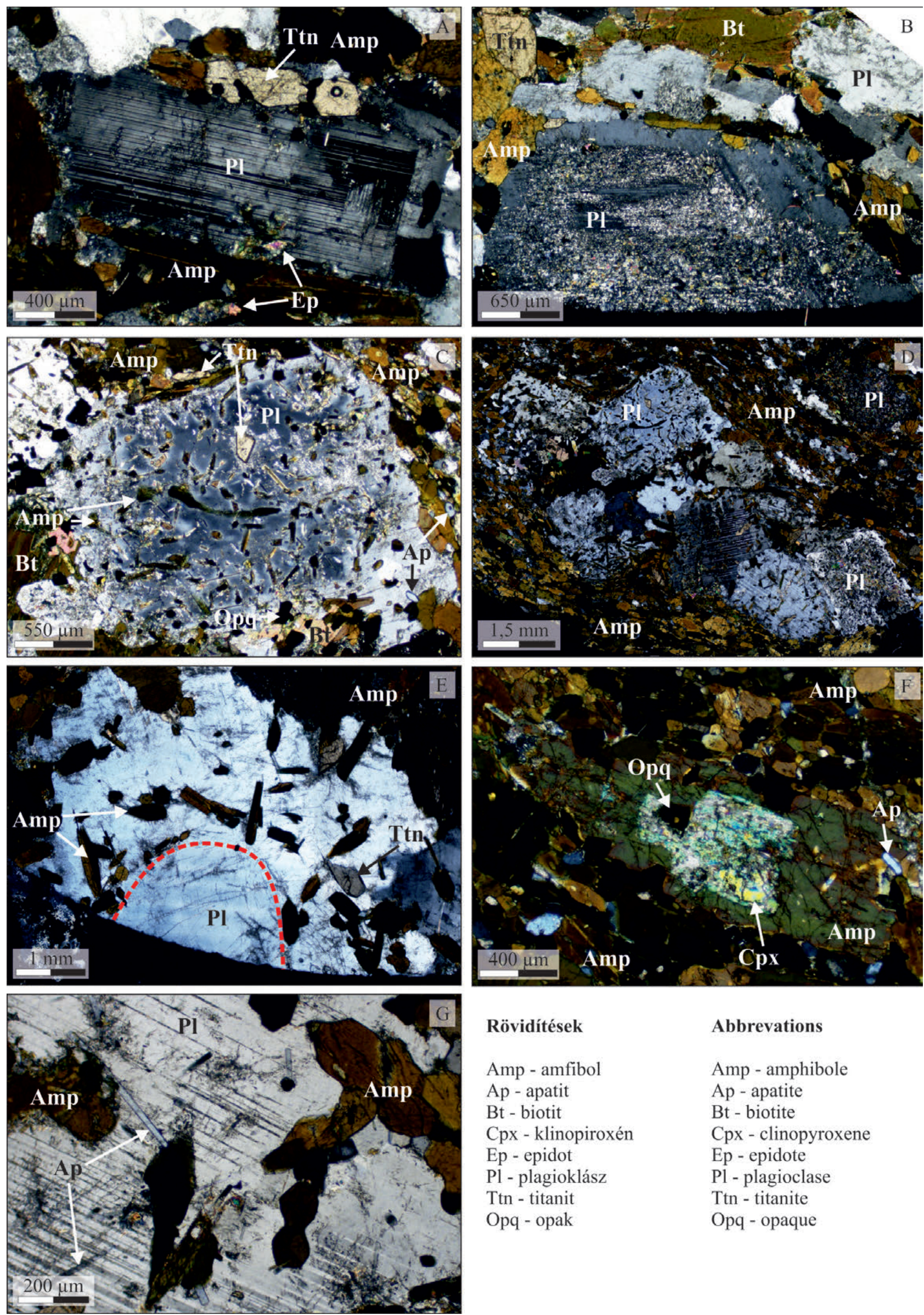

Rövidítések

Amp - amfibol

Ap - apatit

Bt - biotit

Cpx - klinopiroxén

Ep - epidot

$\mathrm{Pl}$ - plagioklász

Ttn - titanit

Opq - opak

\section{Abbrevations}

Amp - amphibole

Ap - apatite

$\mathrm{Bt}$ - biotite

Cpx - clinopyroxene

Ep - epidote

Pl - plagioclase

Ttn - titanite

Opq - opaque 
(4. ábra, H). A piroxének elhelyezkedése a sávokban irányított, a szemcsék kissé lekerekítettek. Az amfibolok alkotta sávokban a szemcsék orientációja olykor kevésbé jellemző, a szemcsék a piroxénekhez hasonlóan kissé lekerekítettek. A DAM területén eddig vizsgált kőzetek közül jelentős mennyiségú piroxént csak a kumulátum kôzetekben írtak le (AlMÁsi et al. 2015, PÁL-MoLNÁr et al. 2015b), de ezekben a piroxének mennyisége jóval kisebb (0-23 térfogat\%), mint az általunk vizsgált ultramafikus kőzetzárványokban. E zárványok makroszkóposan és mikroszkóposan megfigyelhető irányítottsága, valamint az ezek körül megjelenő húlési perem (chilled margin) vagy reakcióperem arra utalnak — hacsak nem egy már eredetileg szilárd, irányított szövetû xenolitról vagy magmatározó faláról származó kumulátumról van szó - , hogy a piroxénhornblendit akár egy kristálygazdag olvadék formájában vehetett részt a magmakeveredési (és/vagy -elegyedési) folyamatokban, és nyomult be a befogadó magmákba.

A feltárás másik, szövetileg eltérő kôzetcsoportja a felzikus kőzetzárvány (hololeukokrata diorit). E kőzettípus a befogadó kőzetekben és a mafikus kőzetzárványokon belül is megjelenhet és gyakran mafikus perem veszi körül. Szövetük hipidiomorf szemcsés, és főként plagioklászból állnak. A magmás környezet illótartalma feltételezhetően átjárja a kőzetzárványt, így átalakítja annak kőzetalkotó ásványait. Az amfibol átalakulását valószínúleg az alkáliák és a $\mathrm{H}_{2} \mathrm{O}$ migrációja okozza (MA et al. 2017). A DAM É-i részén elkülöníthető kőzetek között nem találtunk hasonló megjelenésú és összetételú felzikus kőzettípust, ezért feltételezhetô, hogy a felzikus kőzetzárványok eredete eltér a többi kőzetzárványétól. Az alkotó szemcsék mérete, valamint a lekerekített, visszaoldott peremi részek arra utalhatnak, hogy ezek a plagioklász-gazdag kristálycsomók korábban képződtek, egy másik környezetben. A korábbi kristályosodás során kialakult felzikus kózetet az újonnan benyomuló magma feltépte, és kis mértékben megolvasztva az új magmatározóba szállította. A felzikus zárványok körül megjelenő mafikus perem kialakulása a hőmérséklet-különbségre vezethető vissza (FARNER et al. 2014). A feltépett és új magmás környezetbe került felzikus csomók lokálisan lecsökkentik az olvadék hőmérsékletét, így a plagioklász xenokristályok nukleációs felszínként szolgálnak az amfibol- és biotitszemcsék kristályosodásának. Ennek következtében finomszemcsés ásványhalmaz alakul ki körülöttük (MA et al. 2017). Nem zárható ki továbbá az a lehetőség sem, hogy a befogadó magma és a zárvány határán feldúsuló könnyenillók okozzák a víztartalmú ásványok feldúsulását (FARNER et al. 2014), mint ahogyan ez a többi kőzetzárvány esetében is feltételezhetô. A perem kialakulásában akár mindkét folyamat együttesen is szerepet játszhat. A mafikus peremmel nem rendelkezô felzikus kőzetzárványok esetében a peremek hiányát a magmatározóban lejátszódó konvektív áramlások okozhatják. A mafikus peremet alkotó ásványok gyengébb reológiai tulajdonságai miatt ezek a peremek leválhattak a zárványról, épp úgy, ahogy a slírek kialakulása történik (FARNER et al. 2014). Azoknál a felzikus kőzetzárványoknál, amelyeknél hiányzik a mafikus perem, a zárvány körül a befogadó kőzet erőteljesen irányított. Ez alátámaszthatja az áramló közeg súrlódó hatása okozta peremleválást. A kumulátumok képződése során a mafikus kumulátum felső részén kialakulhat egy felzikus (plagioklász-gazdag) rész, a plagioklászok kisebb súrúségéból adódóan (DUCHESNE \& CHARLIER 2005). Feltételezhető, hogy a felzikus kőzetzárványok ebből a kumulátum-tartományból származnak. A DAM területéról plagioklász-gazdag felzikus kumulátumról korábban nem történt említés. A felzikus kőzetzárványok és a kumulátumok kapcsolatának tisztázása csak további (pl. ásványkémiai) vizsgálatokkal lehetséges.

\section{Összefoglalás}

A Ditrói alkáli masszívum északi részén, a FelsőPietrăriei-patak és az Orotva-patak összefolyásánál található mesterséges feltárásban diorit befogadó kőzet és változatos formájú és megjelenésú mafikus, ultramafikus és felzikus kőzetzárványok különíthetők el. A különböző kőzettípusok részletes makroszkópos és mikroszkópos vizsgálata alapján a következők állapíthatók meg:

1. A szürke, középszemcsés és durvaszemcsés, irányított szövetú befogadó kőzetben (mezokrata diorit) nagy mennyiségú mafikus kőzetzárvány (mezokrata diorit), illetve elszórtan felzikus kőzetzárvány (hololeukokrata diorit); földpátszemes kőzetzárvány (mezokrata diorit); porfíros (földpátaggregátumos), mafikus kőzetzárvány (melanokrata diorit) és ultramafikus kőzetzárvány (piroxénhornblendit) található.

2. A kőzetzárványok leggyakrabban lekerekítettek, ellipszis alakúak és elhelyezkedésük párhuzamos egymással és a befogadó kôzet irányítottságával. A zárványok körül fekete, változó vastagságú, mafikus perem jelenik meg, amely olykor a lencséhez kapcsolódva elnyúlik, vagy önálló szalagok (slírek) formájában látható a befogadó kőzetben. A mafikus perem kialakulása a keveredő magmák dermedési folyamatához (quenching) és/vagy a könnyenillók feldúsulásához kapcsolódik, míg a perem leválása és a zárványok irányítottsága a magmatározóban lejátszódó áramlási folyamatokkal magyarázható. Mindezek a bélyegek a magmakeveredés jellemző tulajdonságai.

3. A kőzettípusokban számos, magmaelegyedéshez köthető mikroszöveti bélyeg figyelhetô meg. Ilyen például a plagioklászok változatos megjelenése (zárványgazdag szemcse zárványszegény peremmel; zárványmentes, viszszaoldódott mag zárványgazdag továbbnövekedéssel, vagy visszaoldódási nyomok). A plagioklász aggregátumok olykor tûs megjelenésú apatitszemcséket tartalmaznak. Lényeges bélyeg továbbá az amfibolköpenyes klinopiroxén is. Ezek a mikroszöveti bélyegek a kristályosodási és kémiai környezet megváltozására utalnak, a különböző fizikai és kémiai tulajdonságú magmák elegyedését feltételezik.

4. A lekerekített, lencse alakú zárványok megjelenése és a kőzetek szöveti irányítottsága alapján feltételezhető, hogy a befogadó kőzet és a kőzetzárványok magmák formájában kerültek interakcióba. Ezzel szemben a felzikus kőzet- 
zárvány (hololeukokrata diorit) már kikristályosodott állapotban kerülhetett a dinamikusan fejlődő magmatározóba.

A feltárásban megfigyelhető makroszkópos és mikroszkópos szerkezeti és szöveti bélyegek, és a szakirodalmi analógiák alapján elmondható, hogy a vizsgált mélységi magmás kőzettest egy tipikus magmakeveredési szerkezetet (mingling structure) mutat. Ennek kialakulása egy kisebb hőmérsékletû, részben már kikristályosodott magmába érkező nagyobb hőmérsékletû olvadék(ok) benyomulásához köthetô. A benyomulás hatására a magmatározó ezen részén dinamikus magmakeveredés zajlott, amely irányított kőzetszövetet eredményezett. Az ásványok a mikroszöveti bélyegek mellett a magmák közötti kristálycsere (crystal transfer) folyamatát is jelzik. Ennek további pontosításához és alá- támasztásához részletes ásványkémiai vizsgálatok szükségesek.

\section{Köszönetnyilvánítás}

A munkánk során nyújtott szakmai segítségért, tanácsokért szeretnénk köszönetünket kifejezni a Szegedi Tudományegyetem Ásványtani, Geokémiai és Kőzettani Tanszékén dolgozó „Vulcano” Kőzettani és Geokémiai Kutatócsoport minden tagjának. BENCSIK Attilának (SZTE Ásványtani, Geokémiai és Kőzettani Tanszék) köszönjük a vékonycsiszolatok elkészítését. ALMÁsı Enikő Eszter kutatói munkáját a Magyar Tudományos Akadémia Domus Hungarica ösztöndíja biztosította.

\section{Irodalom — References}

AlmÁsi E. E., BATKI A. \& KISS B. 2015: Amfibolok petrogenetikai jelentősége a Ditrói alkáli masszívum ultramafikus kumulátum kőzeteiben. — Földtani Közlöny 145/3, 229-246. http://ojs3.mtak.hu/index.php/foldtanikozlony/article/view/133

Anastasiu, N. \& Constantinescu, E. 1979: Structura şi petrogeneza masivului alcalin de la Ditrău. Raport geologic final. — Manuscript, Archiva IPEG Harghita, Miercurea-Ciuc.

Anastasiu, N. \& Constantinescu, E. 1980: Structure du massif alcalin de Ditrău. — Analele Universitatii Bucuresti Seria Geologie 29, $3-22$.

BALINTONI, I. 1997: Geotectonica terenurilor metamorfice din Romania. [Geotectonique from the metamorphic terraines of Romania]. — Editura Carpatica, Cluj-Napoca, 176 p.

BALINTONI, I. \& BALICA, C. 2013: Carpathian peri-Gondwanan terranes in the East Carpathians (Romania): a testimony of an Ordovician, North African orogeny. — Gondwana Research 23/3, 1053-1070. https://doi.org/10.1016/j.gr.2012.07.013

BAlintoni, I., GheuCA, I. \& VoD, Al. 1983: Pânze de încălecare Alpine şi Hercinice din zona sudică şi centrală a Zonei Cristalino Mezozoice din Carpații Orientali. [Alpine and Hercynian overthrust nappes from central and southern areas of the East Carpathians Crystalline Mesozoic Zone]. — Anuarul Instutului de Geologie şi Geofizică al României 60, 15-22.

Balintoni, I., Balica, C., Ducea, M., Chen, F., Hann, H. P. \& Sabliovschi, V. 2009: Late Cambrian - Early Ordovician Gondwanan terranes in the Romanian Carpathians: a zircon U/Pb provenance study. — Gondwana Research 16, 119-133. https://doi.org/ 10.1016/j.gr.2009.01.007

Balintoni, I., Balica, C., Ducea, H. \& Horst-Peter, H. 2014: Peri-Gondwanan terranes in the Romanian Carpathians: A review of their spatial distribution, origin, provenance, and evolution. - Geoscience Frontiers 5/3, 395-411. https://doi.org/10.1016/ j.gsf.2013.09.002

Batki, A., PÁl-MolnÁr, E. \& BÁrdossy, A. 2004: Occurrence and petrology of lamprophyres from the northern part of the Ditrău Alkaline Massif, Eastern Carpathians, Romania. — Acta Mineralogica Petrographica 45/2, 21-28.

Batki, A., PÁl-Molnár, E., Dobosi, G. \& Skelton, A. 2014: Petrogenetic significance of ocellar camptonite dykes in the Ditrău Alkaline Massif, Romania. — Lithos 200-201, 181-196. https://doi.org/10.1016/j.lithos.2014.04.022

Batki, A., PÁl-Molnár, E., Jankovics, M. É., Kerr, A. C., Kiss, B., Markl, G., Heincz, A. \& Harangi, Sz. 2018: Insights into the evolution of an alkaline magmatic system: An in situ trace element study of clinopyroxenes from the Ditrău Alkaline Massif, Romania. — Lithos 300-301, 51-71. http://dx.doi.org/10.1016/j.lithos.2017.11.029

BAXter, S. \& FEely, M. 2002: Magma mixing and mingling textures in granitoids: examples from the Galway Granite, Connemara, Ireland. - Mineralogy and Petrology 76, 63-74. https://doi.org/10.1007/s007100200032

CAmpos, T. F. C., NeIVA, A. M. R. \& NARDI, L. V. S. 2002: Geochemistry of the Rio Espinharas hybrid complex, northeastern Brazil. Lithos 64, 131-153. https://doi.org/10.1016/s0024-4937(02)00199-8

Cashman, K. \& Blundy, J. D. 2013: High-Mg Petrological cannibalism: the chemical and textural consequences of incremental magma body growth. - Contributions to Mineralogy and Petrology 166/3, 703-729. https://doi.org/10.1007/s00410-013-0895-0

Codarcea, A. Codarcea, D.M. \& IANovicI, V. 1957: Structura geologică a masivului de roci alkaline de la Ditrău. — Buletin Ştiințific, Secția de Geologie şi Geografie II/3-4, 385-446.

COUCH, S., SPARKS, R. S. J. \& CARROLL, M. R. 2001: Mineral disequilibrium in lavas explained by convective self-mixing in open magma chambers. — Nature 411, 1037-1039. https://doi.org/10.1038/35082540

DAllmeYER, R. D., KRÄUtNER, H. \& NeubauER, F. 1997: Middle - Late Triassic ${ }^{40}$ Ar $/{ }^{39}$ Ar hornblende ages for early intrusions within the Ditrau Alkaline Massif, Rumania: implications for alpine rifting in the carpathian orogen. _ Geologica Carpathica 48/6, 347-352.

Davidson, J., Turner, S., Handley, H., MacPherson, C., Dosetto A. 2007a: Amphibole "sponge” in arc crust? — Geology 35/9, 787790. https://doi.org/10.1130/G23637A.1 
Davidson, J., Morogan, D. J., Charlier, B. L. A., Harlou, R. \& Hora, J. M. 2007b: Microsampling and Isotopic Analysis of Igneous Rocks: Implications for the Study of Magmatic Systems. - Annual Review of Earth and Planetary Sciences 35/1, $273-311$. https://doi.org/10.1146/annurev.earth.35.031306.140211

Dingwell, D. B. 2009: Magma mixing, mingling and unmixing. — In: Schubert, G. (ed.): Treatise on Geophysics. Vol. 2, Mineral Physics. Elsevier, 420 p.

Duchesne, J. C. \& Charlier, B. 2005: Geochemistry of cumulates from the Bjerkreim-Sokndal layered intrusion (S. Norway). Part I: Constraints from major elements on the mechanism of cumulate formation and on the jotunite liquid line of descent. - Lithos $\mathbf{8 3}$, 229-254. https://doi.org/10.1007/978-94-017-9652-1

Fall, A., Bodnar, J. R., Szabó, Cs. \& PÁl-Molnár, E. 2007: Fluid evolution in the nepheline syenites of the Ditrău Alkaline Massif, Transylvania, Romania. — Lithos 95/3-4, 331-345. https://doi.org/10.1016/j.lithos.2006.08.005

Farner, M. J., LeE, C. A. \& Putirka, K. D. 2014: Mafic-felsic magma mixing limited by reactive processes: A case study of biotite-rich rinds on mafic enclaves. — Earth and Planetary Science Letters 393, 49-59. https://doi.org/10.1016/j.epsl.2014.02.040

Frost, T. P. \& MAHood, G. A. 1987: Field, chemical, and physical constraints on mafic-felsic magma interaction in the Lamarck Granodiorite, Sierra Nevada, California. — Geological Society of America Bulletin 99, 272-291. https://doi.org/10.1130/00167606(1987)99<272:FCAPCO>2.0.CO;2

Georgiev, N., Henry, B., Jordanova, N., Froitzheim, N., Jordanova, D., Ivanov, Z. \& Dimov, D. 2009: The emplacement mode of Upper Cretaceous plutons from the southwestern part of the Sredna Gora Zone (Bulgaria): structural and AMS study. — Geologica Carpathica 60/1, 15-33. https://doi.org/10.2478/v10096-009-0001-8

Gordon, A. 2002: Analysis and interpretation of macrorhythmic units of gabbro-diorite interlayering at Arey Nack, Vinalhaven Island, Maine. - 15 $5^{\text {th }}$ Keck Symposium 15, 1-4.

Hassanen, M. A. 1999: Mantle-crustal Source of Mafic-felsic Magmas in the Dubr-Igla Intrusive Complex, Egypt: Inference from Geochemistry and Sr-Nd Isotopic Study. - Journal of King Abdulaziz University 11, 103-141.

Hibbard, M. J. 1991: Textural anatomy of twelve magma-mixed granitoid systems. — In: Didier, J., Barbarin, B. (eds): Enclaves and Granite Petrology. Elsevier, 431-444.

Hoeck, V., Ionescu, C., Balintoni, I. \& Koller, F. 2009: The Eastern Carpathians “ophiolites” (Romania): remnants of a Triassic ocean. —Lithos 108, 151-171. https://doi.org/10.1016/j.lithos.2008.08.001

Humphreys, M. C. S., Blundy, J. D. \& Sparks, R. S. J. 2006: Magma Evolution and Open-System Processes at Shiveluch Volcano: Insights from Phenocryst Zoning. — Journal of Petrology 47/12, 2303-2334. https://doi.org/10.1093/petrology/egl045

IANOvicI, V. 1933: Étude sur le massif syénitique de Ditrău, région Jolotca, district Ciuc (Transylvanie). — Revista Muzeului GeologicMineralogic al Universității din Cluj 4/2,1-53.

JAKAB, Gy. 1998: Geologia Masivului alcalin de la Ditrău. — Pallas-Akademia, Miercurea-Ciuc, 298 p.

Jakab, Gy., Garbaşevschi, N., Balla, Z., Zakariás, L., Péter, J., Strungaru, T., Hereda, N., Sileanu, T., Aronescu, M., Postolache, C., Mocanu, V., Teulea, G., Hannich, D. \& Tiepac, I. 1987: Sinteza datelor obținute prin prospecțiuni geologice complexe, lucrări miniere şi foraje, executate pentru minereuri de metale rare şi disperse, feroase şi neferoase în masivul de roci alkaline de la Ditrău, județul Hargita. — Manuscript, Archiva IPEG Harghita, Miercurea-Ciuc.

Janoušek, V., Bowes, D. R., Braithwaite, C. J. R. \& Rogers, G. 2000: Microstructural and mineralogical evidence for limited involvement of magma mixing in the petrogenesis of a Hercynian high-K calc-alkaline intrusion: the Kozarovice granodiorite, Central Bohemian Pluton, Czech Republic. - Transactions of the Royal Society of Edinburgh: Earth Sciences 91, 15-26. https://doi.org/10.1130/0-8137-2350-7.15

Janoušek, V., Braithwaite, C. J. R., Bowes, D. R. \& Gerdes, A. 2004: Magma-mixing in the genesis of Hercynian calc-alkaline granitoids: an integrated petrographic and geochemical study of the Sázava intrusion, Central Bohemian Pluton, Czech Republic. Lithos 78, 67-99. https://doi.org/10.1016/j.lithos.2004.04.046

Косн A. 1879: A ditrói syenittömzs kőzettani és hegyszerkezeti viszonyairól. — Magyar Tudományos Akadémiai Értekezések 9/2, 53 p.

KovÁcs G. \& PÁL-Molnár E. 2005: A Ditrói Alkáli Masszívum granitoid kőzeteinek petrogenezise. — Földtani Közlöny 135/1, 121143.

KozUR, H. 1991: The evolution of the Meliata-Hallstatt ocean and its significance for the early evolution of the Eastern Alps and Western Carpathians. - Palaeogeography, Palaeoclimatology, Palaeoecology 87/1-4, 109-135. https://doi.org/10.1016/00310182(91)90132-B

Le Maitre, R. W., Streckeisen, A., Zanettin, B., Le Bas, M. J., Bonin, B., Bateman, P., Bellieni, G., Dudek, A., Efremova, S., Keller, J., Lameyre, J., Sabine, P. A., Schmid, R., Sørenden, H. \& Woolley, A. R. 2002: Igneous Rocks: A Classification and Glossary of Terms. 2nd edition. - Cambridge University Press, 236 p.

LILIENBACH, L. 1833: Journal d'un voyage géologique fait en travers toute la chaíne des Carpathes, en Bucovine, en Transylvanie et dans le Marmarosch. - Mémoires de la Société géologique de France 1, 237-316.

Ma, X., Meert, J. G., Xu, Z. \& ZhaO, Z. 2017: Evidence of magma mixing identified in the Early Eocene Caina pluton from the Gangdese Batholith, southern Tibet. — Lithos 278-281, 126-139. https://doi.org/10.1016/j.lithos.2017.01.020

MCCulloch, L. 2007: Evidence for upward growth of a layered pluton in the Bindal Batholith, north-central Norway. — Texas Tech University, 1-83.

Michel, L., Wenzel, T. \& MARKL, G. 2016: Interaction between two contrasting magmas in the Albtal pluton (Schwarzwald, SW Germany): textural and mineral-chemical evidence. — International Journal of Earth Science. https://doi.org/10.1007/s00531-0161363-7

Morogan, V., Upton, B. G. J. \& Fitton, J. G. 2000: The petrology of the Ditrău alkaline complex, Eastern Carpathians. — Mineralogy and Petrology 69, 227-265. https://doi.org/10.1007/s007100070023 
PanĂ, D., Balintoni, I. \& Heaman L. 2000: Precise U-Pb zircon dating of the syenite phase from Ditrău Alkaline Igneous Complex. — Studia Universitatis Babeş-Bolyai, Geologia 45/1, 79-89.

PÁL-MolnÁr, E. 1988: Studiul mineralogic şi petrologic al complexului Jolotca din masivul alcalin de la Ditrău, cu privire specială asupra mineralelor purtătoare de fier - PhD disszertáció, $127 \mathrm{p}$.

PÁL-Molnár, E. 1992: Petrographical characteristics of Ditró (Orotva) hornblendites, Eastern Charpatians, Transylvania (Romania): a preliminary description. - Acta Mineralogica-Pertrographica 33, 67-80.

PÁL-Molnár, E. 1994a: A Ditrói Szienitmasszívum kialakulása a földtani megismerés tükrében. — A Magyar Tudományos Akadémia Szegedi Akadémiai Bizottságának Kiadványai, Szeged, 85 p.

PÁL-Molnár E. 1994b: Adalékok a Ditrói szienitmasszívum szerkezeti és kôzettani ismeretéhez. — Szegedi Akadémiai Bizottság, Földés Környezettudományi Szakbizottság, 52 p.

PÁL-MolnÁr, E. 1994c: Petrographical characteristics of Ditrău (Orotva) diorites, Eastern Carpathians, Transylvania (Romania). — Acta Mineralogica-Pertrographica 35, 95-109.

PÁL-Molnár E. 1998: A Ditrói szienitmasszívum földtani felépítése és petrológiája, különös tekintettel a hornblenditek és dioritok kialakulására, I-II. - PhD értekezés, JATE, Szeged, 219 p.

PÁL-Molnár, E. 2000: Hornblendites and diorites of the Ditrău Syenite Massif. — Department of Mineralogy, Geochemistry and Petrology, University of Szeged, Szeged, 172 p.

PÁL-Molnár E. 2008: Mezozóos alkáli magmatizmus a Kárpát régióban: a Ditrói Alkáli Masszívum petrogenezise. — OTKA Zárójelentés $46736,80 \mathrm{p}$.

PÁl-Molnár, E. 2010a: Geology of Székelyland. - In: SzaKÁll, S., Kristály, F. (eds): Mineralogy of Székelyland, Eastern Transylvania, Romania, Csík County Nature and Conservation Society, Miercurea Ciuc, 33-43.

PÁL-Molnár, E. 2010b: Rock-forming minerals of the Ditrău Alkaline Massif. — In: SzAKÁLl, S., Kristály, F. (eds): Mineralogy of Székelyland, Eastern Transylvania, Romania. Csík County Nature and Conservation Society, Miercurea Ciuc, 63-88.

PÁL-MolnÁr, E. \& ÁRVA-Sós, E. 1995: K/Ar radiometric dating on rocks from the northern part of the Ditrău Syenite Massif and its petrogenetic implications. - Acta Mineralogica-Pertrographica 36, 101-116.

PÁl-Molnár, E., BAtKi, A., Ódri, Á., Kiss, B. \& AlmÁsi, E. 2015a: Geochemical implications fot the magma origin of granitic rocks from the Ditrău Alkaline Massif (Eastern Carpathians, Romania). — Geologia Croatica 68/1, 51-66. https://doi.org/10.4154/ GC.2015.04

PÁl-Molnár, E., Batki, A., Almási, E., Kiss, B., Upton, B. G. J., Markl, G., Odling, N. \& Harangi Sz. 2015b: Origin of mafic and ultramafic cumulates from the Ditrău Alkaline Massif, Romania. — Lithos 239, 1-18. http://dx.doi.org/10.1016/j.lithos.2015.09.022

Perugini, D., Poli, G., Christofides, G. \& Eleftheriadis, G. 2003: Magma mixing in the Sithonia plutonic complex, Greece: evidence from mafic microgranular enclaves. — Mineralogy and Petrology 78, 173-200. https://doi.org/10.1007/s00710-002-0225-0

Peytcheva, I., von Quadt, A., Georgiev, N., Ivanov, Zh., Heinrich, C. A. \& Frank, M. 2008: Combining trace-element compositions, $\mathrm{U}-\mathrm{Pb}$ geochronology and $\mathrm{Hf}$ isotopes in zircon to unravel complex calcalkaline magma chambers in the Upper Cretaneous Srednogorie zone (Bulgaria). — Lithos 104, 405-427. https://doi.org/10.1016/j.lithos.2008.01.004

SĂNDULESCU, M. 1984: Geotectonica României. — Editura Technică, Bucureşti, 336 p.

SĂndulescu, M., Kräutner, H. G., Balintoni, I., Russo-Săndulescu, M., Micu, M. 1981: The Structure of the East Carpathians (Moldavia - Maramures Area). — Guide Exc. B1, Carp.-Balk. Geol. Assoc., XII Congr. Inst. Geol. Geophys., 92 p, Bucuresti.

Sмiтн D. J. 2014: Clinopyroxene precursors to amphibole sponge in arc crust. — Nature Communications 5/4329, https://doi.org/ 10.1038 /ncomms5329.

Streckeisen, A. 1938: Das Nephelinsyenit-Massiv von Ditro in Rumänien als Beispiel einer kombinierten Differentiation und Assimilation. - Verhandlungen der Naturforschenden Gesellschaft in Basel, 159-161.

Streckeisen, A. 1952: Das Nephelinsyenit-Massiv von Ditro (Siebenburgen), I. Teil. — Schweizerische Mineralogische und Petrographische Mitteilungen 32, 251-308.

Streckeisen, A. 1954: Das Nephelinsyenit-Massiv von Ditro (Siebenbürgen), II. Teil. — Schweizeriche Mineralogische und Petrographische Mitteilungen 34, 336-409.

Streckeisen, A. 1960: On the structure and origin of the Nephelinsyenite Complex of Ditro (Transylvania, Roumania). - 21 $1^{s t}$ International Geological Congress, Rep. $21^{\text {st }}$ Session Norden, 13, 228-238.

Streckeisen, A. \& Hunziker, I. C. 1974: On the origin of the Nephelinesyenite Massif of Ditró (Transylvania, Romania). Schweizerische Mineralogische Petrographische Mitteilungen, 54, 59-77.

Tiepolo, M., Tribuzio, R. \& Langone, A, 2011: High-Mg Andesite Petrogenesis by Amphibole Crystallization and Ultramafic Crust Assimilation: Evidence from Adamello Hornblendites (Central Alps, Italy). — Journal of Petrology 52/5, 1011-1045. https://doi.org/ 10.1093/petrology/egr016

Valesco-Tapia, F., Rodríguez-Saavedra, P., Márquez, A., Navarro de León, I., De Ignacio, C., Marroquín Guerra, G., Quintanilla-GarZA, J. \& RANGel AlvareZ, O. M. 2013: Mineralogical and geological evidence of magma mingling/mixing in the Sierra de las Cruces Volcanic range, Mexican Volcanic Belt. — Journal of Iberian Geology 39, 147-166.

Ubide, T., Galé, C., Larrea, P., Arranz, E., Lago, M. \& Tierz, P. 2014: The Relevance of Crystal Transfer to Magma Mixing: a Case Study in Composite Dykes from the Central Pyrenees. — Journal of Petrology 55/8, 1535-1559. https://doi.org/10.1093/ petrology/egu033

Weidendorfer, D., Mattsson, H. B. \& Ulmer, P. 2014: Dynamics of Magma Mixing in Partially Crystallized Magma Chambers: Textural and Petrological Constraints from the Basal Complex of the Austurhorn Intrusion (SE Iceland). — Journal of Petrology 55/9, 1865-1903. https://doi.org/10.1093/petrology/egu044

Wiebe, R. A., Frey, H. \& Hawkins, D. P. 2001: Basaltic pillow mounds in the Vinalhaven intusion, Maine. — Journal of Volcanology and Geothermal Research 107, 171-184. https://doi.org/10.1016/S0377-0273(00)00253-5 
Wyllie, P. K., CoX, K. G. \& Biggar, M. G. 1962: The Habit of Apatite in Synthetic Systems and Igneous Rocks. — Journal of Petrology 3/2, 238-243. https://doi.org/10.1093/petrology/3.2.238

ZÓLYA, L. \& ZÓLYA, É. G. 1985: A geological study based on geological mapping carried out in 1:5000 scale from the area of the Putna ntunecoas spring (in Romanian). - Manuscript, Archiva IPEG Harghita, Miercurea-Ciuc.

ZóLYA, L.\& ZÓLYA, É. G. 1986: A geological study based on geological mapping carried out in 1:5000 scale from the area of the TilalmasHalaság spring (in Romanian). — Manuscript, Archiva IPEG Harghita, Miercurea-Ciuc.

Kézirat beérkezett: 2017. 05. 25. 